\title{
Life before the minster: the social dynamics of monastic foundation at Anglo- Saxon Lyminge, Kent
}

Article

Published Version

Thomas, G. (2013) Life before the minster: the social dynamics of monastic foundation at Anglo-Saxon Lyminge, Kent. Antiquaries Journal, 93. pp. 109-145. ISSN 1758-5309 doi: https://doi.org/10.1017/S0003581513000206 Available at https://centaur.reading.ac.uk/31300/

It is advisable to refer to the publisher's version if you intend to cite from the work. See Guidance on citing.

To link to this article DOI: http://dx.doi.org/10.1017/S0003581513000206

Publisher: Society of Antiquaries of London

All outputs in CentAUR are protected by Intellectual Property Rights law, including copyright law. Copyright and IPR is retained by the creators or other copyright holders. Terms and conditions for use of this material are defined in the End User Agreement.

www.reading.ac.uk/centaur 
Central Archive at the University of Reading

Reading's research outputs online 


\section{The Antiquaries Journal}

http://journals.cambridge.org/ANT

Additional services for The Antiquaries Journal:

Email alerts: $\underline{\text { Click here }}$

Subscriptions: $\underline{\text { Click here }}$

THE

Commercial reprints: Click here

Terms of use : $\underline{\text { Click here }}$

ANTIQUARIES

JOURNAL

\section{Life before the Minster: the Social Dynamics of Monastic Foundation at Anglo-Saxon Lyminge, Kent}

Gabor Thomas

The Antiquaries Journal / Volume 93 / September 2013, pp 109 - 145

DOI: 10.1017/S0003581513000206, Published online: 20 September 2013

Link to this article: http://journals.cambridge.org/abstract_S0003581513000206

How to cite this article:

Gabor Thomas (2013). Life before the Minster: the Social Dynamics of Monastic Foundation at Anglo-Saxon Lyminge, Kent. The Antiquaries Journal, 93, pp 109-145 doi:10.1017/ S0003581513000206

Request Permissions : $\underline{\text { Click here }}$ 


\title{
LIFE BEFORE THE MINSTER: THE SOCIAL DYNAMICS OF MONASTIC FOUNDATION AT ANGLO-SAXON LYMINGE, KENT
}

\author{
Gabor Thomas, FSA
}

Gabor Thomas, FSA, Department of Archaeology, University of Reading, Whiteknights, Reading RG6 6AB, UK. Email: gabor.thomas@reading.ac.uk

Anglo-Saxon monastic archaeology has been constrained by the limited scale of past investigations and their overriding emphasis on core buildings. This paper draws upon the results of an ongoing campaign of archaeological research that is redressing the balance through an ambitious programme of open-area excavation at Lyminge, Kent, the site of a royal double monastery founded in the seventh century AD. The results of five completed fieldwork seasons are assessed and contextualised in a narrative sequence emphasising the dynamic character of Lyminge as an Anglo-Saxon monastic settlement. In so doing, the study brings into sharp focus how early medieval monasteries were emplaced in the landscape, with specific reference to Anglo-Saxon Kent, a regional context offering key insights into how the process of monastic foundation redefined antecedent central places of long-standing politico-religious significance and social action.

\section{EXCAVATING EARLY MEDIEVAL MONASTIC SETTLEMENTS: AN ASSESSMENT OF PREVIOUS WORK}

In the archaeology of later medieval monasticism it has become established practice to target outer precincts and wider settings as a vital tool for contextualising the core buildings and as a prerequisite for embedding monastic sites within contemporary landscapes and settlement patterns. ' That Anglo-Saxon monasteries of the pre-Viking era demand the same approach to investigation as their later medieval counterparts has long been appreciated by archaeologists and the analytical construct 'monastic landscape' is now firmly established in the archaeological literature on Anglo-Saxon monasticism. ${ }^{2}$ Yet, as has been lamented in recent assessments, the keyhole scale of past research and its overriding emphasis on core buildings means that there are barely any case studies from this period that provide a holistic account of the spatial organisation of a monastic institution in its landscape setting, nor of the physical characteristics of its component parts. ${ }^{3}$ As a consequence, archaeology remains largely underexploited as a tool for examining the institutional and regional diversity that emerged as

I. As reflected in the emphasis of such texts as Gilchrist and Mytum 1989 and Bond 2004.

2. Rahtz (1973) was well aware of the requirement; see Pestell 2004 for a recent application of this construct in an East Anglian context.

3. Blair 20II, 733, and Gittos 20II, 829; Loveluck (2007b, I86) makes the same observation for early medieval monasteries on the Frankish Continent. 
divergent traditions of monastic culture were assimilated across the cultural patchwork of the early Anglo-Saxon kingdoms. ${ }^{4}$

The rare glimpses that have been obtained from the outer precincts of documented Anglo-Saxon monasteries and their British/northern Frankish counterparts serve as a reminder why a more extensive approach to sampling monastic sites is required in the preViking period. Previous investigations at Hartlepool, Hoddom and Whitby, for example, indicate that these outlying zones might stretch a considerable distance from the monastic core, thereby offering a vital perspective on scale; they also harbour crucial evidence for the organisation of domestic accommodation and economic activity and are frequently accompanied by rubbish deposits that offer important insights into the spatial patterning of daily social practices within religious communities. ${ }^{5}$ Moreover, as demonstrated at Hartlepool and Ripon, monastic houses belonging to the upper echelons of the pre-Viking ecclesiastical hierarchy might comprise several widely dispersed spiritual foci, each with an attendant cemetery serving a different sector of the religious/lay population. ${ }^{6}$ The basic lesson is that early medieval monastic settlements were sprawling and topographically complex entities that cannot be properly understood by small-scale, piecemeal investigation.

It is instructive to examine how the constraints of past research have marginalised monastic archaeology from broader disciplinary developments. Over the past twenty years the field of Anglo-Saxon settlement studies has been transformed by the discovery of a wealth of new sites and associated data, generated by commercial archaeology and targeted research excavation. ${ }^{7}$ Conspicuous amongst this new generation of sites are such high-status Middle Saxon settlements as Flixborough, Brandon and Bishopstone, all sharing exceptionally rich assemblages of portable material culture and/or bioarchaeological remains, resulting from relatively large excavation areas and intensive sampling regimes designed to maximise yields from associated refuse deposits. ${ }^{8}$ Much debate has been expended on whether or not these sites might represent unrecorded monastic communities for all or part of their occupation sequences. ${ }^{9}$ As the evidence currently stands, however, it is simply not possible to make nuanced archaeological comparisons - and thus establish patterns of similarity and difference - between these sites and excavated settlements with a reliably known monastic pedigree. Even where similarly informative refuse disposal zones have been encountered on monastic excavations - Hartlepool being a notable example - the interpretative potential of the data is invariably compromised by inconsistent sampling strategies resulting in serious gaps in understanding. ${ }^{\text {IO }}$

One area of interpretation where the rift between Anglo-Saxon monastic archaeology, on the one hand, and rural settlement archaeology, on the other, is particularly apparent is site dynamics: how settlements developed over time and their relationship to sites of antecedent activity. Arguably one of the most significant insights to emerge from the commercial excavation of Middle Saxon rural settlements is their complex and extended histories of development, as reflected in marked temporal changes in spatial organisation,

4. For discussions of this process, see Blair 2005, 5-6, 8-48; Foot 2006, II.

5. Blair 2005, I99 n 76; Lowe 2006; Daniels 2007. For a synthesis of the Frankish evidence, see Loveluck 2005, 24I-6; for comparative Irish sites, see O'Sullivan et al 2010, 7I-6.

6. Hall and Whyman 1996; Daniels 2007.

7. For a recent synthesis of the expanded settlement corpus, see Reynolds 2003 and Hamerow 2012.

8. Carr et al 1988; Loveluck 2007a; Thomas 2010a.

9. Loveluck 200I; Pestell 2004, 36-64; Blair 2005, I9I-2I2.

Io. Huntley and Rackham 2007. 
the built environment and patterns of economic consumption. ${ }^{\text {II }}$ A recurring element of these complex settlement histories is the reoccupation of early Anglo-Saxon sites, often accompanied by a shift in location or a spatial reorganisation. ${ }^{\mathrm{I2}}$ As has recently been noted by Cramp, Anglo-Saxon monasteries offer their own perspective on this phenomenon, for under excavation they too commonly produce glimpses of antecedent activity, whether pre-existing burial foci or vestiges of lay settlement, a characteristic shared by institutions in Celticspeaking regions of early medieval Britain. ${ }^{13}$ Yet the evidence is usually so fragmentary that it has little concrete to offer in terms of addressing in what ways the siting and spatial configuration of ecclesiastical communities actively referenced, assimilated and adapted elements of an ancestral landscape, a process that has much to teach us about how Christianity was embedded into the social, ideological and political fabric of the early Anglo-Saxon kingdoms. ${ }^{\mathrm{I}}$ With one or two notable exceptions, our archaeologically informed impression of Anglo-Saxon monastic institutions (beyond the architectural development of their core churches) is comparatively static, an impression that is hard to reconcile with their often long-recorded documentary histories.

The implication of this brief assessment is that open-area excavation, backed by intensive sampling regimes, has an important role to play in revitalising the research agenda for Anglo-Saxon monastic archaeology: without such an approach we are denied a clear view of how monastic sites of the period behaved as settlements both in relation to each other and to the broader repertoire of rural central places that emerged in the Anglo-Saxon landscape between the sixth and eighth centuries AD. This paper is based upon a continuing programme of research that is attempting to redress the balance by deploying one of the most ambitious campaigns of excavation ever undertaken on a major documented monastic institution of the pre-Viking period. The target is Lyminge, one of a network of royal double houses established within the Anglo-Saxon kingdom of Kent in the wake of St Augustine's mission in AD 597. Since its initiation in 2007, five seasons of open-area excavation have been completed within the core of the village, augmented by trial trenching and extensive geophysical survey, taking advantage of a series of unoccupied parcels of land clustered around the historic site of the churchyard.

Covering an area in excess of $6,000 \mathrm{~m}^{2}$, these investigations have mapped an extensive stratigraphic horizon of Anglo-Saxon archaeology embracing a 400-year occupation sequence separated into two spatially distinct phases: the earlier dating from the later fifth to the seventh century $\mathrm{AD}$, and the later, contemporary with Lyminge's documented period as a monastic community, from the later seventh to the later ninth century AD. Both phases of settlement produced large volumes of domestic refuse, the earlier predominantly from

II. The key site to demonstrate such transitions is Flixborough: Loveluck 200I; 2007a, I44-62; for a wider perspective on the topic of early medieval settlement dynamics in the British Isles, see Thomas 2012, 44-50.

I2. Hamerow (2012, 78-83) examines a selection of rural settlements displaying such continuity; for general context, see Reynolds 2003, IOI.

13. Cramp 2005, 355.

I4. The relationship of Anglo-Saxon monastic communities to the past expressed in the assimilation of pre-existing sites and embedded cultural traditions is discussed by Blair $2005,5 \mathrm{I}-8$, I83-91. Carver (2009) explores similar themes in relation to the Celtic-speaking regions of early medieval Britain, drawing upon the results of his research at the Pictish monastery at Portmahomack. Several essays in De Jong and Theuws 200I offer a wider western European perspective on how early medieval monastic institutions articulated with pre-existing 'topographies of power'. 
sunken-featured buildings and the later from boundary ditches and pits. These deposits were targeted by a systematic strategy of dry sieving all stratified contexts and extensive bulk sampling for environmental flotation, the latter resulting in an abundance of bioarchaeological evidence, including prodigious quantities of fish bone and plant macrofossils preserved through carbonisation and mineralisation.

The aim of this paper is to assess and contextualise these discoveries in a chronological narrative, emphasising the dynamic character of Lyminge as an early medieval monastic landscape. But before engaging directly with the evidence it is first necessary to examine more closely the regional context framing the research and its academic aims.

\section{CENTRAL PLACES AND MONASTIC FOUNDATION: A REGIONAL ARCHAEOLOGICAL PERSPECTIVE}

Historical sources make clear that royal courts, the initiators and prime instigators of early medieval Christianisation, served as catalysts for the spread of monastic culture across the Anglo-Saxon kingdoms. ${ }^{\text {I5 }}$ If this is the case, how did the new tier of monastic establishments articulate with pre-existing centres of royal power, the royal vills (villae regiae) glimpsed in contemporary historical sources? This question has been much debated by archaeologists seeking to understand how excavated Middle Saxon settlements relate to the historical processes of Christianisation and monastic foundation. Particular uncertainty concerns broad swathes of lowland England, where the archaeological character of royal vills is very opaque and where the process of identifying monastic sites on the ground is obfuscated by poor levels of historical documentation. ${ }^{16}$ John Blair, FSA, one of the key contributors to this debate, has argued that in such regions the two categories of site should be accorded independent trajectories, whereby 'the normal relationship between royal minster and royal power-centre seems to have been one of proximity rather than absolute contiguity'. ${ }^{17}$ At the core of Blair's thesis lies an assertion that the two classes of site behaved very differently in terms of their relative stability: whereas monastic settlements were predisposed towards long-term stability, we are encouraged to view royal centres as mutable phenomena 'with short lives to be measured in decades rather than centuries', ${ }^{18}$ that approximated to 'multifunctional central areas rather than monumentally permanent complexes'. ${ }^{19}$ Other scholars have conceptualised the relationship in different terms. Morris, Pestell and Loveluck, for example, argue that the direct attachment of monastic communities to pre-existing royal vills to form multifunctional settlement complexes, far from being exceptional, may very well represent a common trajectory in the life history of Anglo-Saxon central places. ${ }^{20}$

One can argue about the general applicability of these competing models, but it is important to consider regional diversity in settlement patterns as a factor that is likely to have had a significant - if admittedly still poorly defined - influence on the archaeological character of royal/aristocratic power centres during the period of Anglo-Saxon monastic

I5. Yorke I999; 2006, I22-8, I6I-70.

I6. Ulmschneider 20II, I62.

I7. Blair I992, 231.

I8. Blair 2005, 276.

I9. Ibid, $280 \mathrm{n} \mathrm{I63.}$

20. Morris I989, I3I-3; Pestell 2004, 63-4; Loveluck 2009, I45. 
expansion. In the opinion of Blair, one region that has some claim to be genuinely distinctive in respect of its central-place archaeology is Kent. ${ }^{2 \mathrm{I}}$ Critical scrutiny of historical and toponymic sources, now complemented by an enlarged body of archaeological data, supports the view that a stable network of royal vills crystallised across the landscape during the political consolidation of the Kentish kingdom over the later sixth and seventh centuries AD. ${ }^{22}$ The trajectory of several, though not all, of these places was marked by the establishment of royal monasteries over the course of the seventh century - typically double houses inspired by monastic traditions on the Frankish Continent and transmitted to Kent through dynastic marriage alliances and other high-level political contacts. ${ }^{23}$

It remains to be seen whether Kent is genuinely anomalous in respect of the stability of its early royal vills or, alternatively, whether this is a modern distortion resulting from the comparatively rich survival of early historical sources. For now, our main concern is to exploit this contextual framework to establish general patterns in the character and development of local sites; this objective will be met by considering the following three themes, providing a Kentish perspective on broader research agendas in Anglo-Saxon monastic archaeology. ${ }^{24}$

I. The social dynamics of monastic foundation: if it is indeed the case that monastic foundations in the kingdom were implanted into a stable network of royal vills, Kent provides an opportunity to gain a much-needed perspective on the dialectical relationship between monastic communities and the host settlements into which they were implanted. In what ways were long-established sites of ceremonial and political importance, and the modes of cultural behaviour centred upon them, altered by the experience of monastic foundation and to what extent were antecedent cultural traditions assimilated into the new social and ideological structures of monastic life?

2. The archaeology of Anglo-Saxon double monasteries: the notable concentration of double houses in Kent forms one of the most distinctive elements of its early ecclesiastical organisation. ${ }^{25}$ To what extent can the identity of these femaledominated religious communities be recognised archaeologically, perhaps through aspects of spatial zoning and gendered material practices? And how might this evidence compare to that recovered from excavated counterparts in other regions of Anglo-Saxon England?

3. Monastic networks: all the old head minsters within the diocese of Canterbury the smallest diocese in Anglo-Saxon England - were established under the patronage of the Kentish royal house within a period of two to three generations during the seventh century AD. ${ }^{26}$ Historical sources indicate that close institutional links existed between members of the monastic nexus during the pre-Viking era (for example, between Minster-in-Thanet and Lyminge, $c \mathrm{AD} 800$ ) and the double houses in particular were closely integrated within royal familial networks through

21. Blair 2005, 278.

22. Everitt I988, II6-I7; Brookes 201 I.

23. Blair $2005,42,84-5$; see note 25 below.

24. The first of these perspectives provides the principal focus for the current study.

25. The key modern historical studies on the Anglo-Saxon double house are Foot 2000 and Yorke 2003; for the local Kentish context, see Rigold I968; archaeological aspects are covered in Gilchrist 1994, 25-36, and Daniels 2007, 172-5.

26. Tatton-Brown 1988, I05. 
the agency of a presiding princess-abbess. ${ }^{27}$ There is thus a clear case for conceptualising the Kentish situation in similar terms to the monastic networks and confederacies argued to have existed in other regions of Anglo-Saxon England and on the Frankish Continent. ${ }^{28}$ Previous work has shown that Kentish minsterchurches share strong architectural affinities, although there has perhaps been a tendency to over-homogenise them into a uniform group. ${ }^{29}$ To what extent might activity and occupation material excavated from the outer precincts of documented sites shed new light on any shared cultural identity?

Kent's potential to contribute to these research themes in Anglo-Saxon monastic archaeology has been stifled by a legacy of past enquiry dominated by the investigation (and in some cases the desecration) of core buildings and the excavation of unsatisfactorily small areas. Opportunities to remedy this situation in recent years have been few and far between. Most new evidence has been confined to commercial archaeology in the larger urban centres of Canterbury and Dover, where the excavation windows have been comparatively small and subsequent site development has resulted in considerable disturbance to the Anglo-Saxon phases, presenting many challenges to their interpretation. Meanwhile, the archaeological potential of rural minsters located within the built-up cores of occupied villages has remained largely untapped because these locales are rarely subject to development on a scale prompting commercial excavation. The potential insight to be gained from 'infill' housing developments and the construction of public amenities (such as schools and village halls) is certainly not to be underestimated, yet much of this small-scale development, especially that undertaken before the introduction of formal planning guidance in the I990s, has unfortunately passed undetected under the archaeological radar.

\section{SETTING THE SCENE: LYMINGE AS A CASE STUDY}

One point on which all modern historical assessments agree is that there can be no certainty on the origins of a monastic community at Lyminge. Popular tradition ascribes its foundation in the year AD 633 to Queen Æthelburh, daughter of Æthelberht I of Kent and widow of King Edwin of Northumbria, but the veracity of association - derived as it is exclusively from post-Norman Conquest hagiography - has been shown to be insecure. As the historian Susan Kelly has recently reminded us, the earliest direct reference to a monastic establishment at Lyminge dates from $c$ AD 700, in the first of a series of royal charters extending down into the mid-ninth century $\mathrm{AD}^{30}$ One of the interesting implications raised by her review of the sources is the possibility that Lyminge emerged as a double monastery only during the final third of the seventh century, plausibly as the re-foundation of a pre-existing royal mortuary chapel. ${ }^{3 \mathrm{I}}$ Unfortunately, it is not currently possible to test this proposal in the archaeology of the core buildings under the churchyard (see more on this below), although the identification in 2012 of a monumental timber hall on a nearby site certainly constitutes important new evidence for a seventh-century

27. Brooks 1996, I83-5; Blair 2005, 85.

28. Foot 2006, 25I-82; Morris 2008, 22-3 and n I50.

29. Cambridge I999.

30. Kelly 2006.

3I. Ibid, IO4. 
royal connection. No less relevant to the issue of the site's development is Kelly's observation that the social composition of the monastery fluctuated over time. Indeed, a charter of the 840 s refers to Lyminge as a community of priests and other male clerics, the implication being that its original identity as a double house may not have outlived the Viking incursions of the early ninth century. ${ }^{32}$

Knowledge of the core buildings of the Anglo-Saxon monastery derives from discoveries made by the antiquary Canon Jenkins in a series of investigations from I853 within and immediately to the south west of the limits of the churchyard. ${ }^{33}$ As a result of some rather fanciful interpretation in Jenkins's published accounts the precise nature of these masonry foundations remains unclear and some elements of what he recorded have divided modern scholarship. The generally held view is that Jenkins encountered (and in publication erroneously conflated) the remains of two separate Anglo-Saxon structures: a seventh-century AD minster-church partly superimposed by the south wall of the standing parish church; and a second structure with a western apse located immediately to the south west of the church tower that has been subject to a recent small-scale reinvestigation. ${ }^{34}$

Although important Anglo-Saxon discoveries of non-monastic character had been made in the environs of Lyminge since Canon Jenkins's day, the inception of the current

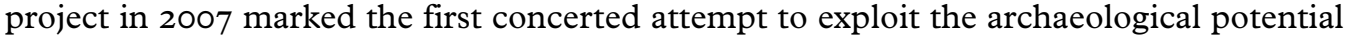
of the open spaces surrounding the churchyard to contextualise the poorly recorded monastic core. ${ }^{35}$ Lyminge is perhaps unique among the sites of Kentish rural minsters in that the historic nucleus of the village is relatively undeveloped, which provides opportunities for open-area excavation on a scale rarely possible within the confines of currently occupied villages. It is this factor, combined with the relatively undisturbed nature of the buried Anglo-Saxon archaeology, that is enabling Lyminge's evolution as an early medieval monastic landscape to be charted in detail.

The remainder of this paper sets out the key phases in Lyminge's archaeological development, taking the opportunity where appropriate to address their wider significance to key themes in Anglo-Saxon monastic archaeology and to settlement archaeology more generally. The narrative begins with an examination of Lyminge's early Anglo-Saxon origins, commencing with a reassessment of existing cemetery evidence. This is followed by a discussion of newly discovered settlement remains of the later fifth to the mid-seventh century $\mathrm{AD}$, the first archaeological evidence from Kent to provide an evolutionary perspective on the emergence of the domestic/ceremonial component of a native royal vill. Developments are then tracked forwards in time through an examination of Middle Saxon (later seventh- to ninth-century $\mathrm{AD}$ ) activity, relating to the outer precinct of the monastic-period settlement. Finally, selected components of Lyminge's nationally important zooarchaeological assemblage - including the largest collection of fish bone yet

32. Ibid, II2-I3.

33. Recent discussion of these remains, including references to the main literature, embracing both modern scholarship and publications dating back to Jenkins's day, can be found in Kelly 2006, 99-100.

34. Ibid.

35. The initial impetus for the current research was provided by an archaeological evaluation undertaken in the summer of 2005 in a parcel of land adjoining the southern boundary of the churchyard. Directed by Paul Bennett of the Canterbury Archaeological Trust in his capacity as Diocesan Archaeologist (the parish had applied for a faculty to extend burial into this area), the intervention recovered a dense concentration of Middle Saxon occupation features that have since been shown to represent a portion of the domestic sector of the monastic precinct. 
recovered from a rural settlement in Anglo-Saxon England - are examined to chart diachronic changes in lifestyle and economic regime over the 400-year occupation sequence.

\section{MONASTIC ANTECEDENTS: LYMINGE BETWEEN THE LATER FIFTH AND MID-SEVENTH CENTURIES AD}

The case for identifying Lyminge as an Anglo-Saxon royal vill, or component thereof, has been rehearsed on several previous occasions, drawing upon relevant toponymic, historical and archaeological sources. ${ }^{36}$ One of the key strands of evidence is the name Lyminge itself: the suffix $g \bar{e}$ (shared by the Kentish royal vills of Eastry and Sturry) represents a primitive naming convention signifying the centres of Anglo-Saxon administrative districts. ${ }^{37}$ In this case the district name (Limenwara) is derived from the River Limen, a coastal branch of the River Rother in the vicinity of modern-day West Hythe. This identification has left one basic question unanswered: why did the inland site of Lyminge come to take on the name of a district synonymous with a coastal feature? To account for this toponymic translocation, some scholars have speculated that royal and ecclesiastical administration within the lathe of Limenwara may have been divided respectively between the coastal progenitor of Lympne and a secondary offshoot at Lyminge. ${ }^{38}$

A review of the archaeological evidence now available for early Anglo-Saxon Lyminge demonstrates unequivocally that its roots as a royal monastic foundation lay in an independent trajectory stretching back into the fifth century $\mathrm{AD}$ to the earliest horizon of Anglo-Saxon cultural identity in Kent. Whatever path of development Lympne may have taken over a corresponding period (the archaeological record is currently silent on this issue), there is now little reason to doubt that Lyminge was already an established royal centre by the time it emerged with a monastic component at the end of the seventh century. Confirmation for this assertion rests largely on recent domestic settlement evidence recovered from the core of the village, but first it is worth briefly revisiting the cemetery evidence in the locality in acknowledgement of the fact that the mortuary arena appears to have played a powerful role in the life of central places in early Anglo-Saxon England. ${ }^{39}$ What follows is informed by a recent landmark study on the neighbouring royal vill of Eastry that, through systematic integration of old and new cemetery finds, was able to generate important archaeological insights into the incipient development of politico-religious centres in early Anglo-Saxon Kent. ${ }^{40}$

\section{The cemetery evidence}

Although the cemetery evidence for Lyminge is less complete than it is for Eastry, there are strong hints that the two locales shared several features in common. First is a multiplicity of prominently sited burial grounds whose placement on routeways was arguably

36. Everitt 1988, 77; Kelly 2006, I05; Brookes 201 I, I59.

37. Brooks I989, 7I-3.

38. Rollason I982, 48; Everitt 1988, 20, 77, 90, 342; Blair 2005, I86 n I6.

39. See Williams 2002 for a sensitive treatment of this topic contextualised against the background of early medieval central places in Scandinavia.

40. Dickinson et al 20II. The mortuary signatures identified in this study can be usefully applied to the incipient phases of other Kentish district centres. 


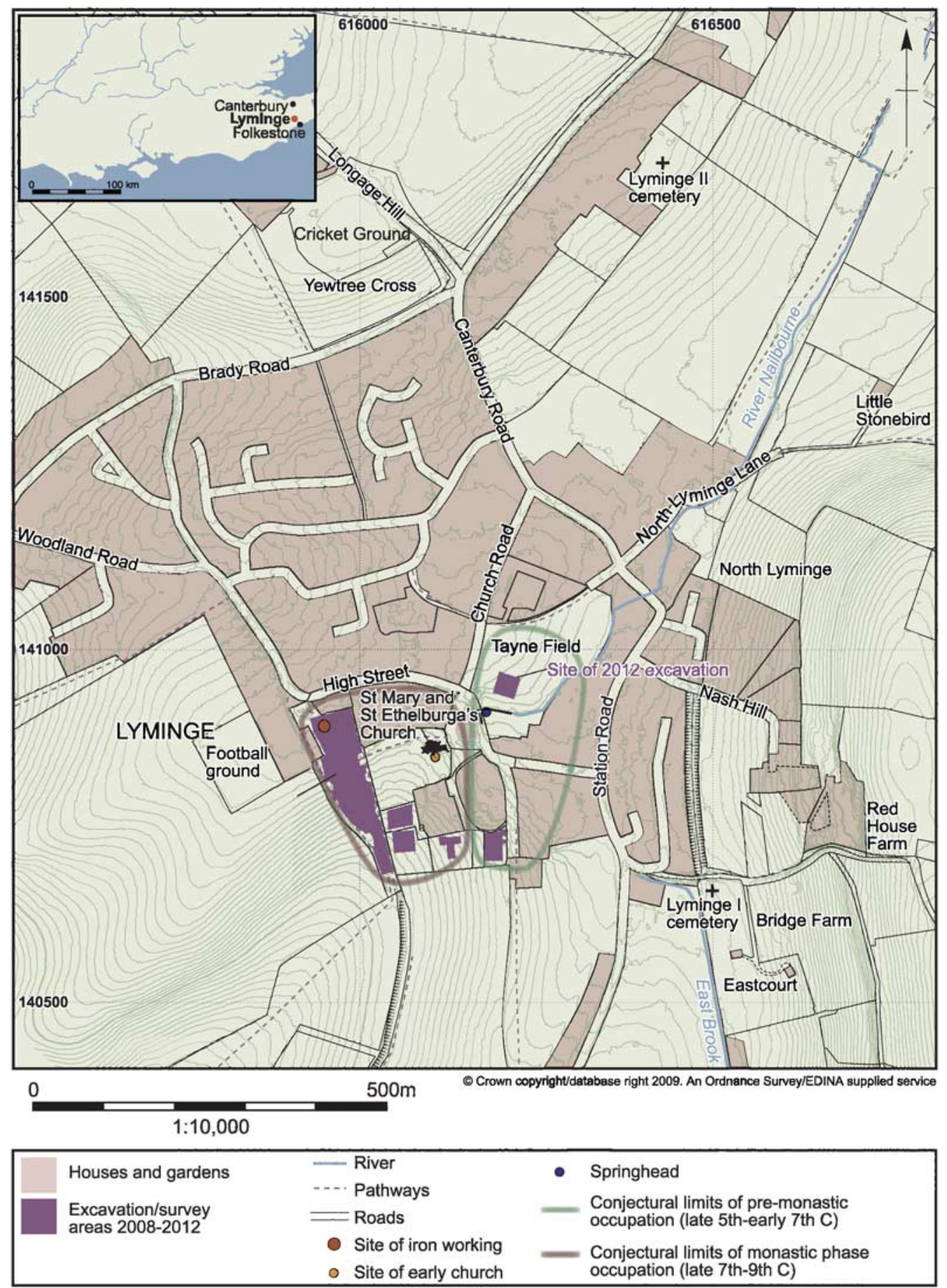

Fig I. The topography of Lyminge village and its immediate environs, showing the location of excavations undertaken in 2008-I2 and the conjectured extents of the sixthand seventh- century and eighth- and ninth-century settlement foci. Drawing: Sarah Lucas 


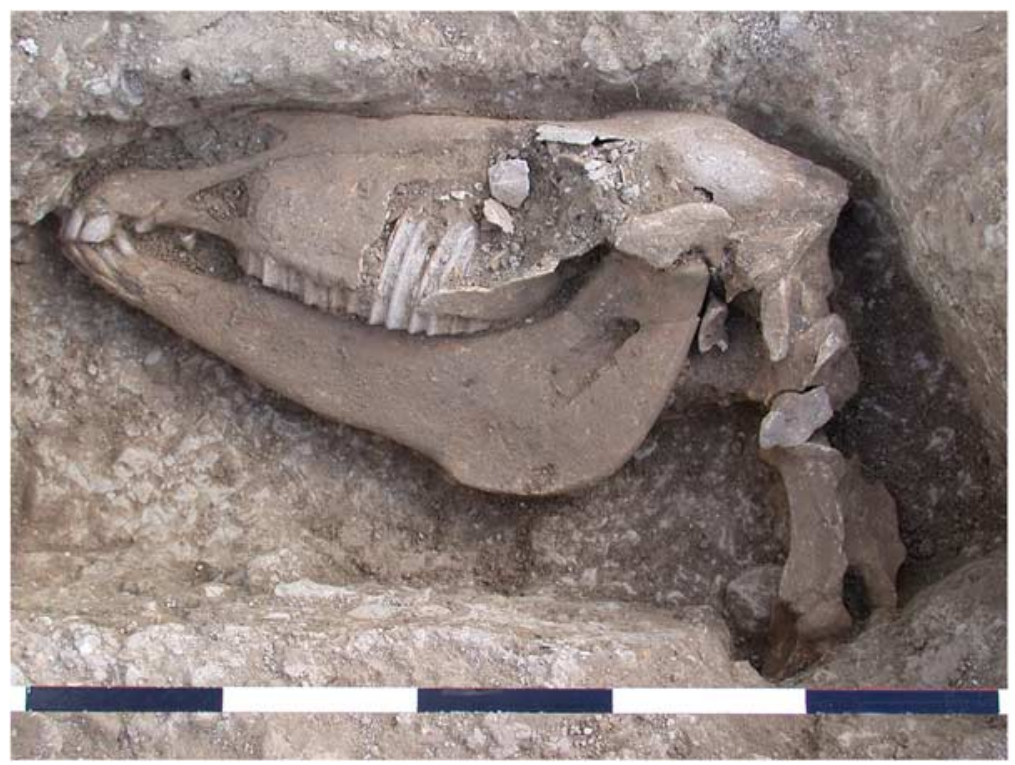

Fig 2. View of the horse burial found at the Lyminge II Anglo-Saxon cemetery. Photograph: by kind permission of the Canterbury Archaeology Trust

exploited to make statements of power, lineage and authority. ${ }^{4 \mathrm{I}}$ Lyminge has two known cemeteries: Lyminge I, sited on a westward-facing slope at the southern extremity of the village, some $280 \mathrm{~m}$ south east of the parish church, and Lyminge II, capping a spur overlooking the River Nailbourne on the northern outskirts of the modern settlement (Fig I). ${ }^{42}$ As has been hypothesised at Eastry, the Lyminge pairing may have served as symbolic entry points into an inner settlement enclave, in this case nestled within the north-south axis of the Elham Valley, a natural communication route linking the coastal chalklands of south-east Kent with the catchment of the River Stour in the vicinity of Canterbury. ${ }^{43}$

Lyminge and Eastry also acted as focal points for elite burials, common characteristics of which provide direct insights into their shared role as politico-religious centres during the pre-Christian era. Particularly significant in this regard is a horse burial (Grave II7) encountered during a recent unpublished campaign of excavation at Lyminge II, a discovery that finds echoes in the later sixth-century $\mathrm{AD}$ horse-and-warrior grave from Updown, Eastry, reconstructed from the Cobb Collection of antiquarian finds held by Maidstone Museum. ${ }^{44}$ Although only the head and upper part of the horse's neck were exposed in articulation during the small-scale intervention, the burial's proximity and

4I. For a detailed examination of this theme in Anglo-Saxon Kent, see Brookes 2007.

42. Richardson 2005, II, 48-9.

43. Dickinson et al 20II, 72-3. It is significant to note that Lyminge's territorial centrality holds when the focus is widened to encompass the distribution of early Anglo-Saxon cemeteries within the lathe as a whole (Brookes 2011, I60, fig 67).

44. The discovery is mentioned in Richardson 2005, II, 48. I should like to thank Keith Parfitt for supplying additional information on the find, including the published photograph. For a discussion of the Updown, Eastry burial, see Dickinson et al 201 I, 30-56. 
alignment (south-north) with surrounding graves affirms its contemporaneity with the cemetery (Fig 2). ${ }^{45}$ It may be further noted that the horse is identifiable as a young adult male of five to eight years of age, according with a general preference for stallions/geldings in the early medieval tradition of horse sacrifice. ${ }^{46}$ One can only speculate, but the absence of accompanying bridle/harness fittings might suggest that the Lyminge burial falls into a mature (late sixth- to early seventh-century) horizon of the tradition when horse and rider were typically (as at Eastry) interred separately, with equestrian equipment invariably being deposited with the latter. ${ }^{47}$ Although the evidence for this important new find is less complete than one would like, it establishes that the rite of horse sacrifice was practised at Lyminge. As highlighted by Fern, the enactment of such a rite within the mortuary arena not only gave expression to a powerful association between equestrianism and elite masculinity in early Anglo-Saxon England, but also alluded to ancestral myths and genealogies that were probably exploited by ruling groups as tools of hegemony and political legitimisation. ${ }^{48}$

A further dimension of the Kentish mortuary record relating to pagan cult activity is provided by sixth-century $\mathrm{AD}$ female graves equipped with Scandinavian-derived gold bracteates: a notable cluster of such graves has been identified in the block of landscape between Eastry, Woodnesborough and Finglesham (alongside other finds bearing Wodeninspired iconography), ${ }^{49}$ but it is significant to note that Lyminge II has produced its own example. ${ }^{50}$ Behr has argued convincingly that such bracteates should be understood as more than simply items of prestige jewellery, but as a 'potent and visible means in the development of early medieval kingship', grounded in an ideology of Scandinavian mythic origins captured at a later date in Anglo-Saxon royal genealogies. ${ }^{5 \mathrm{I}}$ Moreover, the find circumstances of the Kentish bracteates - the fact that they are derived from the wealthiest female graves, predominantly from sites with attested royal associations - suggest that 'women of the highest rank in early Anglo-Saxon society in Kent played an ostentatious role in the religious and ideological legitimization of early Kentish kingship'. ${ }^{52}$ Lyminge, the site of a documented double monastery placed under the control of a royal abbess, is thus one of the few places where the continuity of aristocratic women in the role of religious practitioners can be traced directly into the Christian period at a specific locale in the Anglo-Saxon landscape.

This comparative review demonstrates that Lyminge's Anglo-Saxon mortuary archaeology has rather more to offer in terms of characterising its incipient phases as a Kentish district centre than hitherto recognised. Many of the traits used to track Eastry's development as an early Anglo-Saxon politico-religious focus are present at Lyminge,

45. The fact that the horse burial was cut by an Anglo-Saxon cremation (Grave 108) provides added support for this attribution.

46. Fern 2007 , I00. I should like to thank Robin Bendrey for his assistance in providing a zooarchaeological identification and Chris Fern for discussing its significance.

47. Fern 2007, 96; Dickinson et al 20II, 54.

48. Fern 2007, I02. Dickinson et al (201 I, 73) argue that the horse-and-warrior barrow burial at Updown, Eastry is likely to denote a royal companion forming 'one of a small number of mounted elite warriors, with command over men on foot'.

49. Dickinson et al 2011, 67.

50. Richardson 2005, II, 48. A second (now lost) bracteate, purportedly from Lyminge I (ibid, 49), can probably be dismissed as a misidentification. I thank Charlotte Behr for discussing this piece with me.

5I. Behr 2000, 5I.

52. Ibid, 52 . 
albeit more fragmentarily attested. Overall, the various correspondences indicate that Lyminge played host to a rich and successful household or households whose sixthcentury rise to prominence mirrored that of competing lineages visible in the mortuary profile of neighbouring Kentish central places such as Eastry and Dover. Further, evidence for pagan religious observance adduced from the mortuary record suggests that Lyminge would have been imbued with powerful cosmological meanings: a place of cult worship where elaborate funerary displays were exploited to forge a collective sense of ancestry, identity and social memory. ${ }^{53}$

\section{The domestic settlement evidence}

Domestic settlement remains dating to this early period were sampled in campaigns of excavation in 2010 and 2012 . Separated by a distance of some $200 \mathrm{~m}$, both sites occupy the lower eastward-facing slopes of the Elham Valley in the vicinity of the headwater of the River Nailbourne, which emerges from a spring at the base of a chalk promontory now capped by the parish church (Fig I). Both sites demonstrate a sequence of early AngloSaxon occupation extending from potentially as early as the later fifth century AD through until the middle of the seventh. This correspondence suggests that a single cohesive settlement is represented, perhaps spanning as much as $300 \mathrm{~m}$ to $400 \mathrm{~m}$ north-south, but it is a matter of speculation whether the spread of occupation was continuous or was instead made up of several defined spatial clusters.

In its earliest phases (up to the end of the sixth century) the settlement consisted of a combination of earth-fast timber halls, denoted by alignments of postholes, and sunkenfeatured buildings, arranged in a fairly diffuse layout typical of 'migration-period' settlements (Fig 3). ${ }^{54}$ Good structural detail survived only for one of the earth-fast structures dating to this period, but it is likely to characterise other buildings of the same phase whose survival is more fragmentary. Constructed on an east-west axis, this building measured $12.8 \mathrm{~m}$ long by $4.6 \mathrm{~m}$ wide and was distinguished by pairs of posts aligned widthways, denoting a constructional technique known as 'transverse assembly' (Fig 4). There was evidence that some of the uprights, including those marking the opposed, long-wall entrances, had been scalped into planks to remove the outer sapwood. It is worth noting that the dimensions of this building, with a length approximately three times that of its width, departs from the standard, two-square module plan typifying timber halls of the early Anglo-Saxon period; indeed, the fact that this anomalous characteristic is paralleled at the local site of Church Whitfield, Dover, may hint towards the existence of a regionally distinctive architectural tradition. ${ }^{55}$

The structural characteristics of the sunken-featured buildings accord well with evidence recovered from the wider repertoire of Anglo-Saxon settlements, particularly those in eastern England: four- and six-post assembly are represented, as is evidence for the refurbishment and/or rebuilding of structures on the same footprint, indicated by the replacement of principal uprights and recut pits. ${ }^{56}$ One of the structures displayed evi-

53. For detailed consideration of these themes, see Williams 2006; Devlin 2007.

54. Hamerow 2012, 67-7I. It may be noted that the relatively low ratio of sunken-featured buildings to post-built halls seen at Lyminge is typical for early Anglo-Saxon settlements located on chalk geology (Tipper 2004, 24).

55. Welch $2007,35$.

56. Tipper 2004, 68-70; Hamerow 2012, 55. 

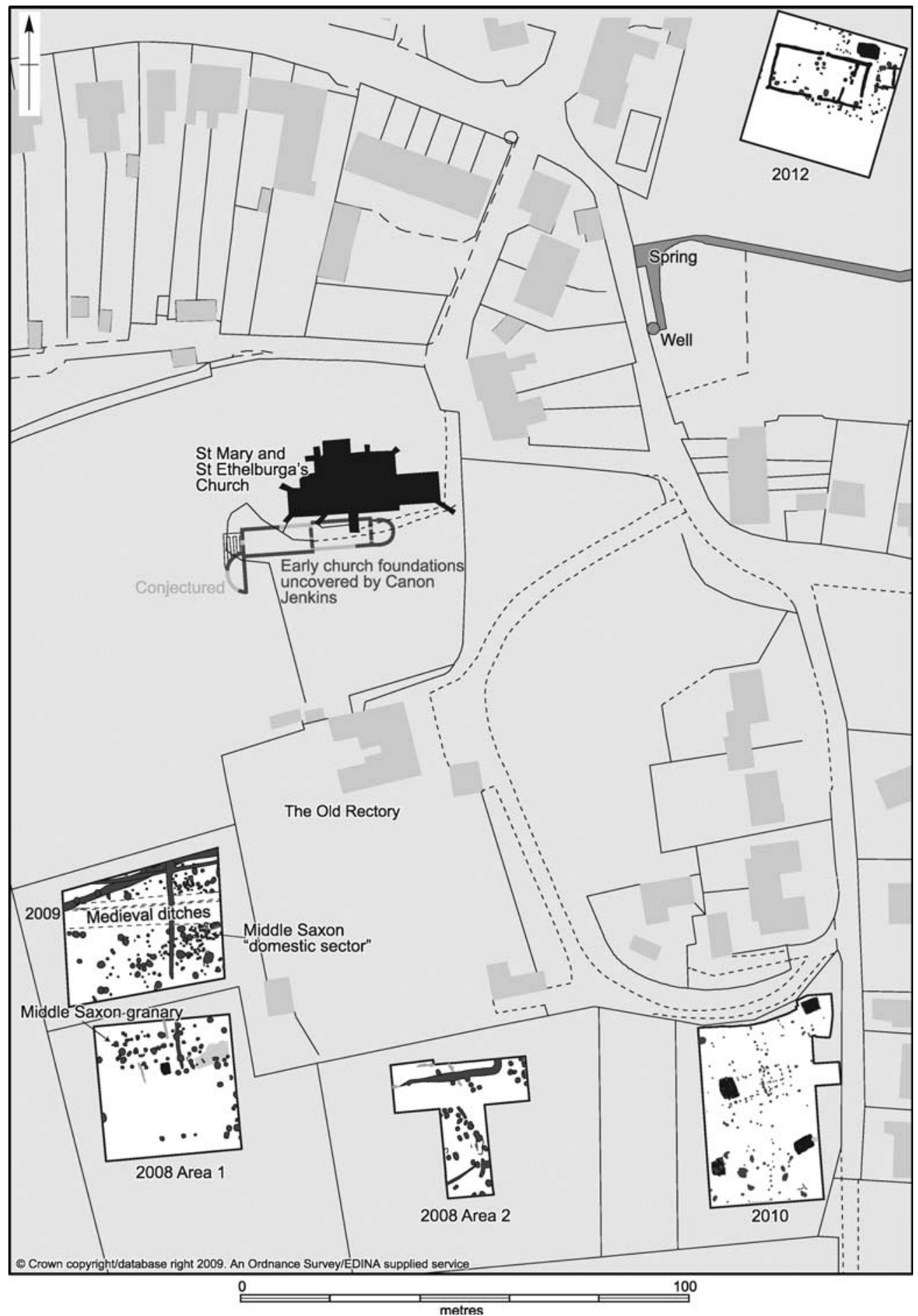

Fig 3. Trench plans showing Anglo-Saxon features excavated since 2008. Drawing: Sarah Lucas/Alexandra Knox 


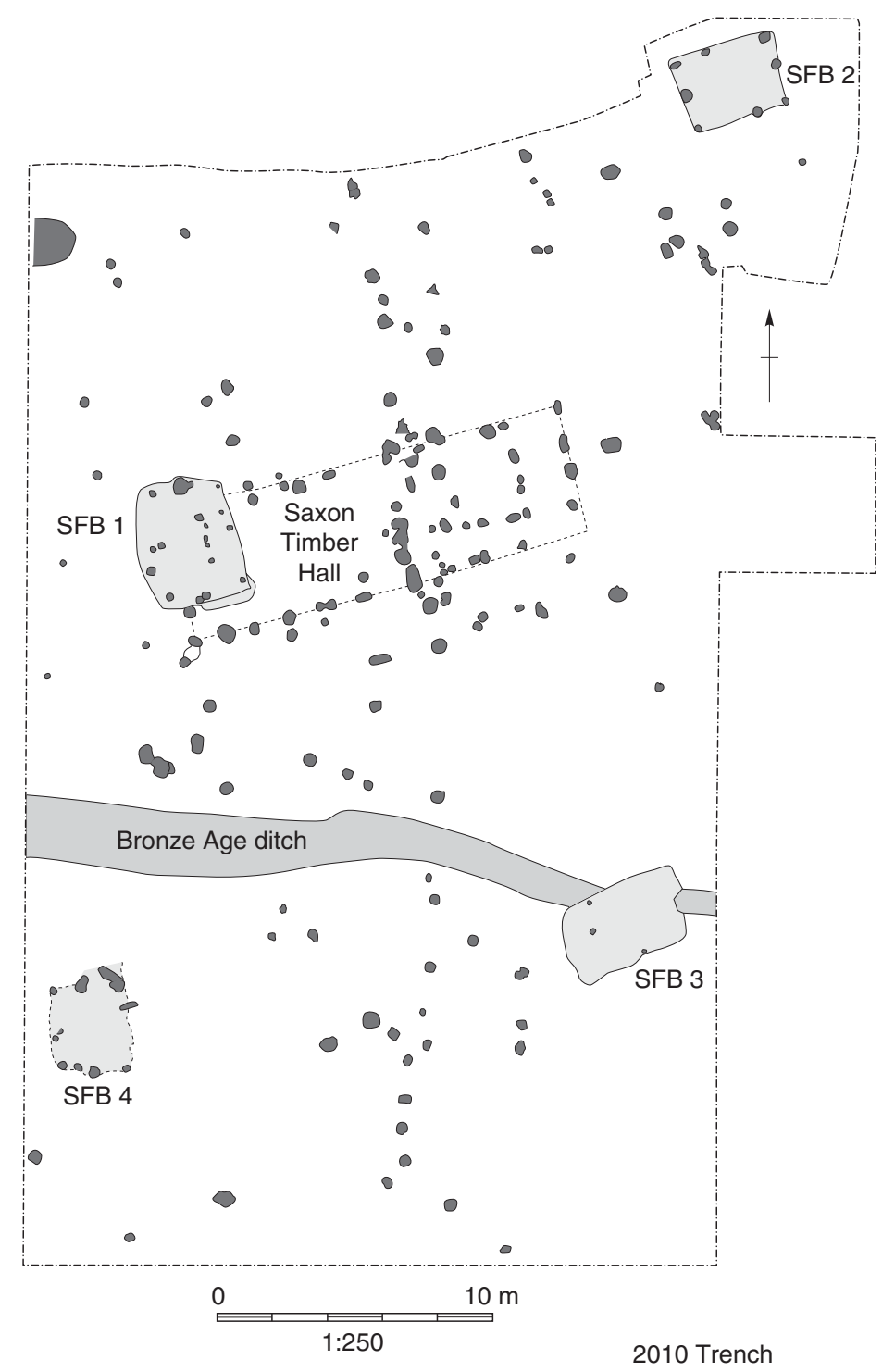

Fig 4. Detailed plan of archaeological features forming a component of the sixthand seventh-century settlement focus excavated in 2010. Drawing: Sarah Lucas

dence for longitudinal alignments of stakeholes along the base of the pit, a phenomenon noted at other sites that is hard to reconcile with the theory that these particular examples were furnished with suspended floors. ${ }^{57}$

All the sunken-featured buildings that have been excavated so far share unusually rich refuse deposits, rapidly dumped at the point of the structure's abandonment (Fig 5). ${ }^{8}$

57. Ibid, 58 .

58. Research by Tipper (2004, 104-7) demonstrates that the pits of most Anglo-Saxon sunkenfeatured buildings were infilled as part of post-abandonment depositionary sequences. 


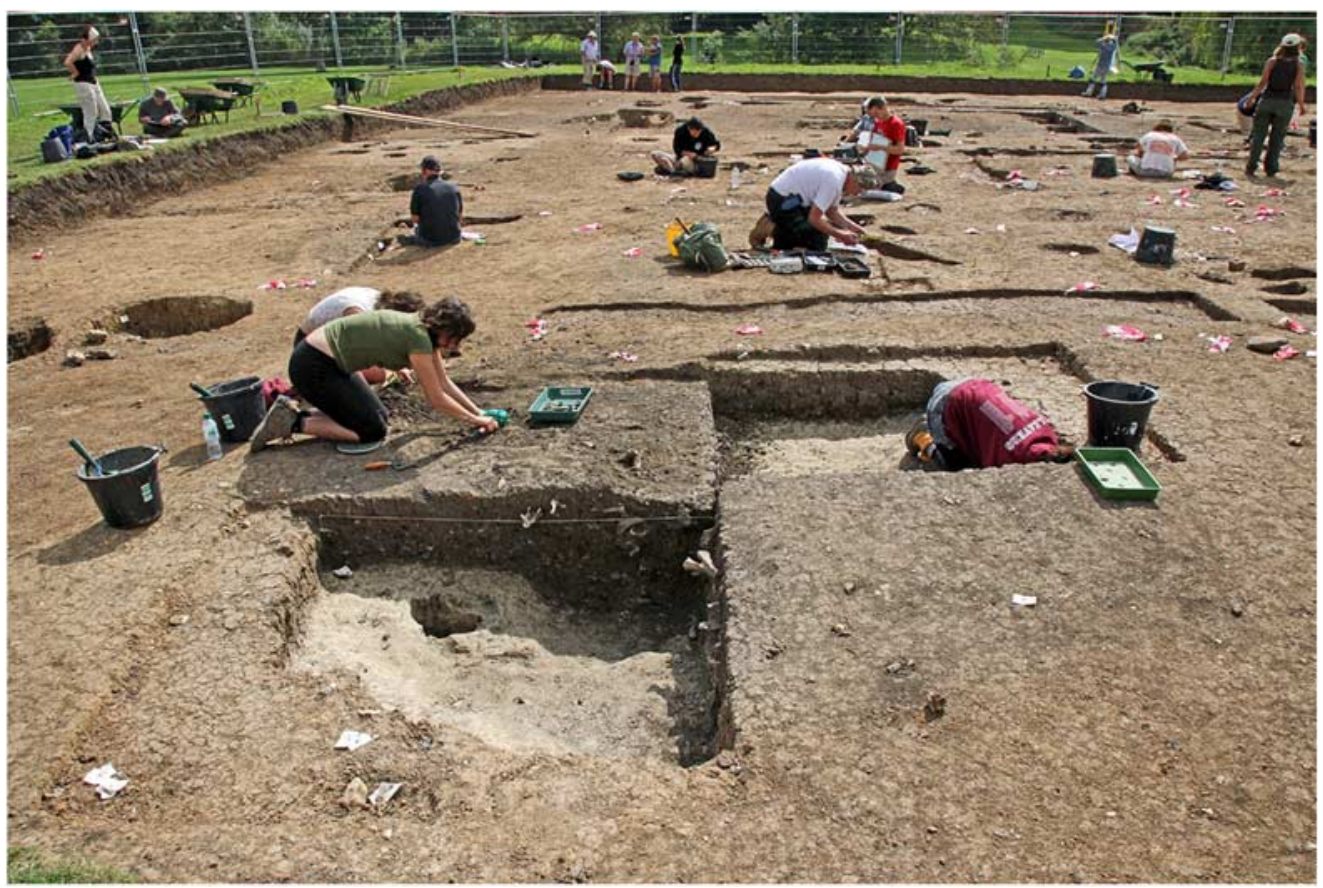

Fig 5. View of a sunken-featured building under excavation in 2012 showing rich deposits of animal bone and associated domestic refuse. Photograph: author

The richness of these deposits in comparison to other sites can be attributed partly to the fact that, in addition to redeposited surface middens (ie, tertiary waste) argued by Tipper to characterise the depositionary histories of most sunken-featured buildings, they also contain 'secondary' refuse transported directly from domestic interiors and related activity areas. ${ }^{59}$ These contrasting sources of refuse are clearly distinguishable in the differential fragmentation patterns of ceramics and faunal remains (cultural material associated with the latter is generally less fragmented and abraded than that attributable to the former) and in the character of the sediments themselves, as revealed by micromorphological and geochemical analysis. ${ }^{60}$ The identification of several associated bone groups within the faunal assemblages of the sunken-featured buildings, combined with the discovery of a complete iron plough coulter deposited at the base of the pit of SunkenFeatured Building (SFB) I, while further demonstrating the complex nature of their depositionary life histories, also suggests that Lyminge will be able to bring new refinements to our current understanding of 'special deposits' on Anglo-Saxon settlements. ${ }^{6}$

The abundant artefactual and bioarchaeological assemblages recovered from the sunken-featured buildings chime with the cemetery evidence in identifying Lyminge as a

59. Hamerow 20I2, 6I.

60. Maslin 2012.

6I. See Hamerow 2006 for a discussion of 'special deposits' on early Anglo-Saxon settlements. A sample of the associated bone groups from Lyminge is listed in Baker (2012, 5); for brief summaries of the plough coulter, see Thomas 2011 and Thomas and Knox 2012, fig 3. 


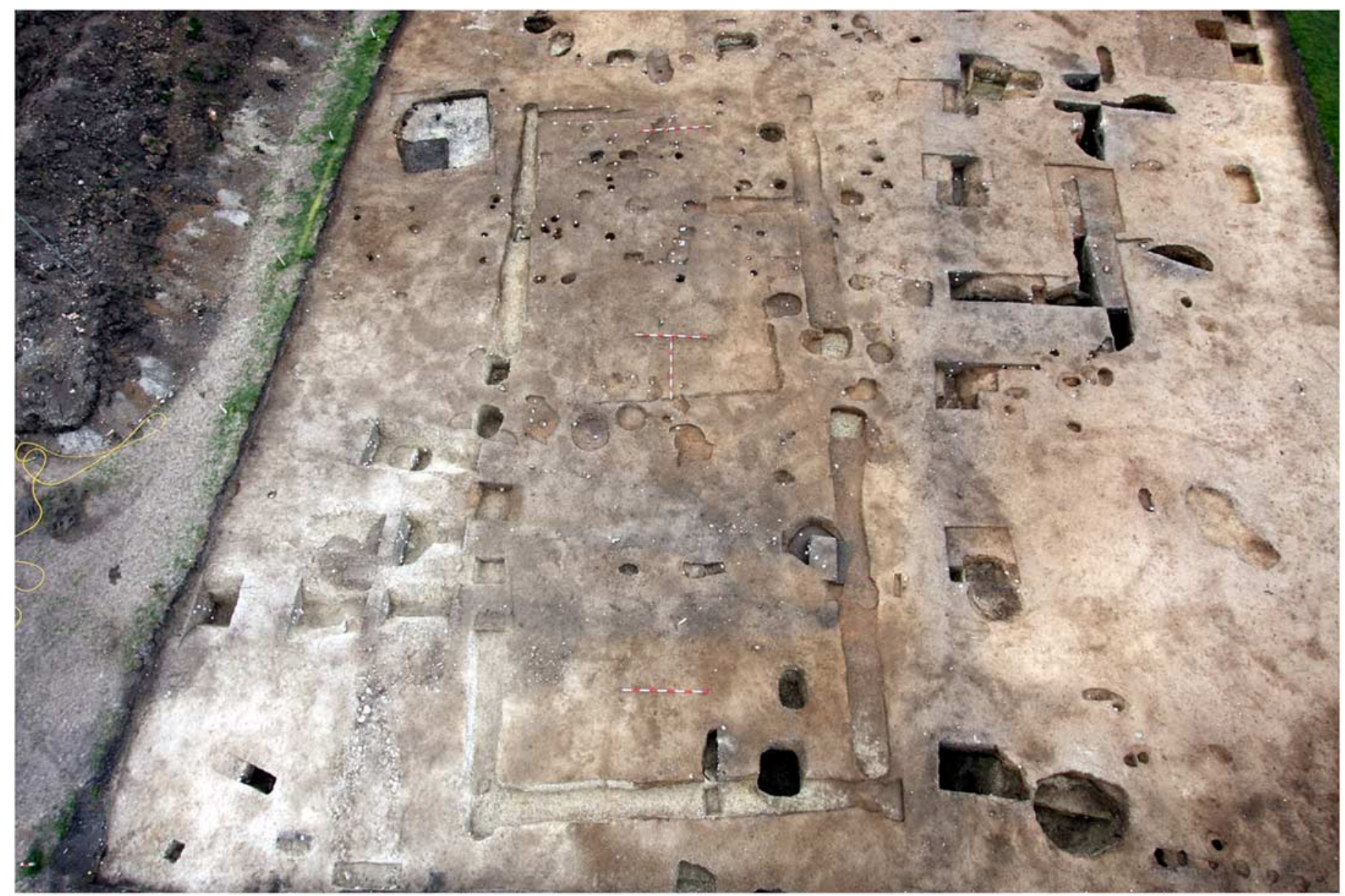

Fig 6. View looking eastwards down the long axis of the great hall excavated in 20I2. Photograph: Hawkeye Elevated Photography 


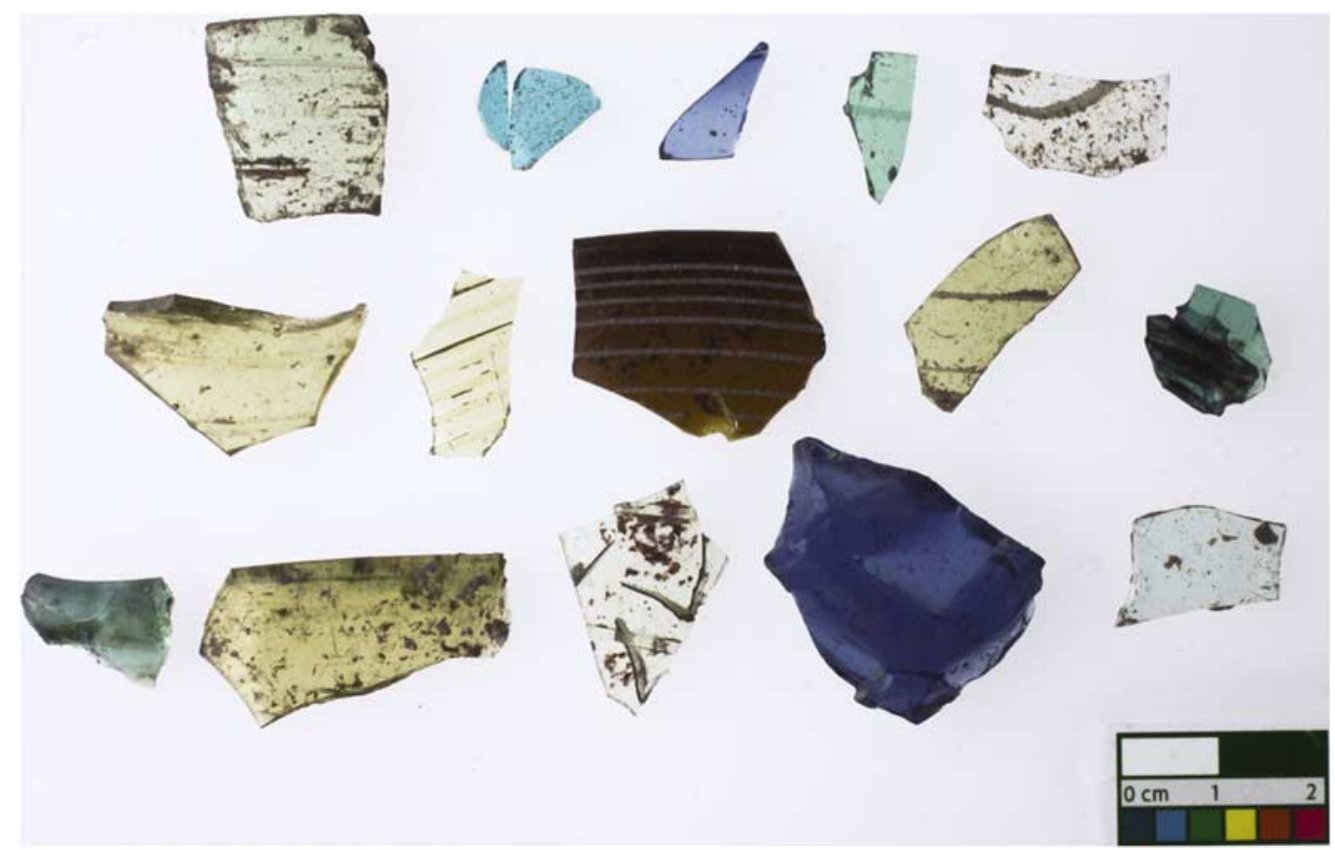

Fig 7. Selected Anglo-Saxon vessel glass recovered from the 2012 excavations. Photograph: Rose Broadley

focus of high-status activity during the sixth century AD. ${ }^{62}$ This characterisation is most clearly signalled in an impressive assemblage of vessel glass covering a diversity of forms paralleled in high-status furnished graves, a context of discovery which in Kent, as in other regions of early Anglo-Saxon England, offers a rather more representative view of the paraphernalia of contemporary 'feasting kits' than do contemporary Anglo-Saxon settlements. ${ }^{63}$ A similar conclusion is supported by an unusually high proportion of pig within the faunal assemblage, a phenomenon that Lyminge shares with a wide repertoire of secular elite settlements in Anglo-Saxon England and further afield. ${ }^{64}$ Charter sources demonstrate that the seasonal pasturing of pigs in Wealden 'dens' was fundamental to the economy of early Anglo-Saxon Kent and formed the basis of its early territorial structure. ${ }^{65}$ Lyminge provides one of the first sizeable, well-dated pig assemblages offering the potential for a detailed examination of the biological characteristics of those herds and related husbandry regimes.

62. The characterisation is based on assessments of the portable material culture (Scull 20II) and the zooarchaeological assemblages (Baker 2012).

63. At least II glass vessels are represented in the 6th-century deposits sampled in 2010's excavation within the southern portion of the early Anglo-Saxon settlement (Scull 20I I, 8-IO). For background on the social significance of glass vessels during this period, see Evison 2008, 3-8; Loveluck 2009, I46. Broadley (201I) provides an overview of all the glass recovered from Lyminge up to 20I0, including a significant assemblage of Middle Saxon vessel and window glass from the monastic-phase settlement.

64. Loveluck 2009, I50-I.

65. The classic study of this economic regime is Witney 1976. 


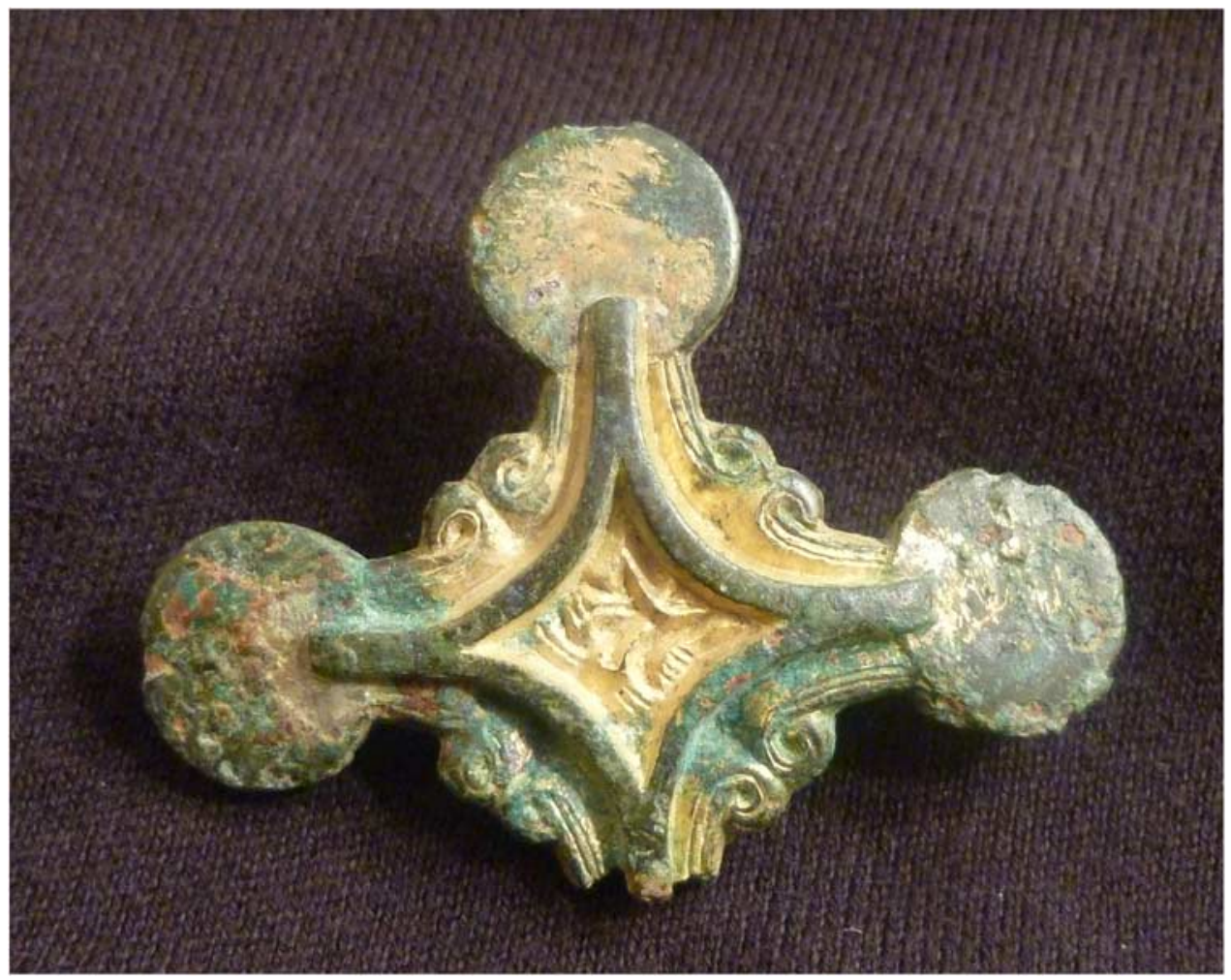

Fig 8. Gilt copper-alloy horse-harness mount bearing Style I zoomorphic decoration recovered from the eastern end-wall trench of the great hall. Photograph: Dana Goodburn-Brown

The character of the early Anglo-Saxon settlement focus was radically transformed when a monumental timber hall was constructed on the plateau of a low spur skirted by the headwater of the River Nailbourne - a site previously occupied by sunken-featured buildings and modest timber halls forming a portion of the original settlement (Fig 3). In scale and construction this building displays close affinities with other so-called 'great halls' that first appeared in the Anglo-Saxon landscape around AD 600 in association with the earliest generation of recognisable royal vills and aristocratic power centres (Fig 6). ${ }^{66}$ The Lyminge hall measured $2 \mathrm{Im}$ long by $8.5 \mathrm{~m}$ wide externally and had an internal partition at its eastern end. It was of post-in-trench construction, the outer walling made

66. For general discussion of these structures, see James et al 1984 and Hamerow 2012, I02-9. A good Kentish parallel for the Lyminge hall was recorded during multiple phases of rescue excavation in Dover in the late I970s. The excavator has interpreted the Dover structure as a timber minster-church (Philp 2003, 58-72), a view since challenged by Welch $(2007,203)$, who argues for a secular interpretation on the strength of its close affinities with similar halls from royal/aristocratic sites such as Yeavering and Cowdery's Down. The latter attribution is supported by the evidence from Lyminge, which demonstrates unequivocally that the timber hall had an existence quite separate from the masonry church lying at the heart of the later monastic complex. 


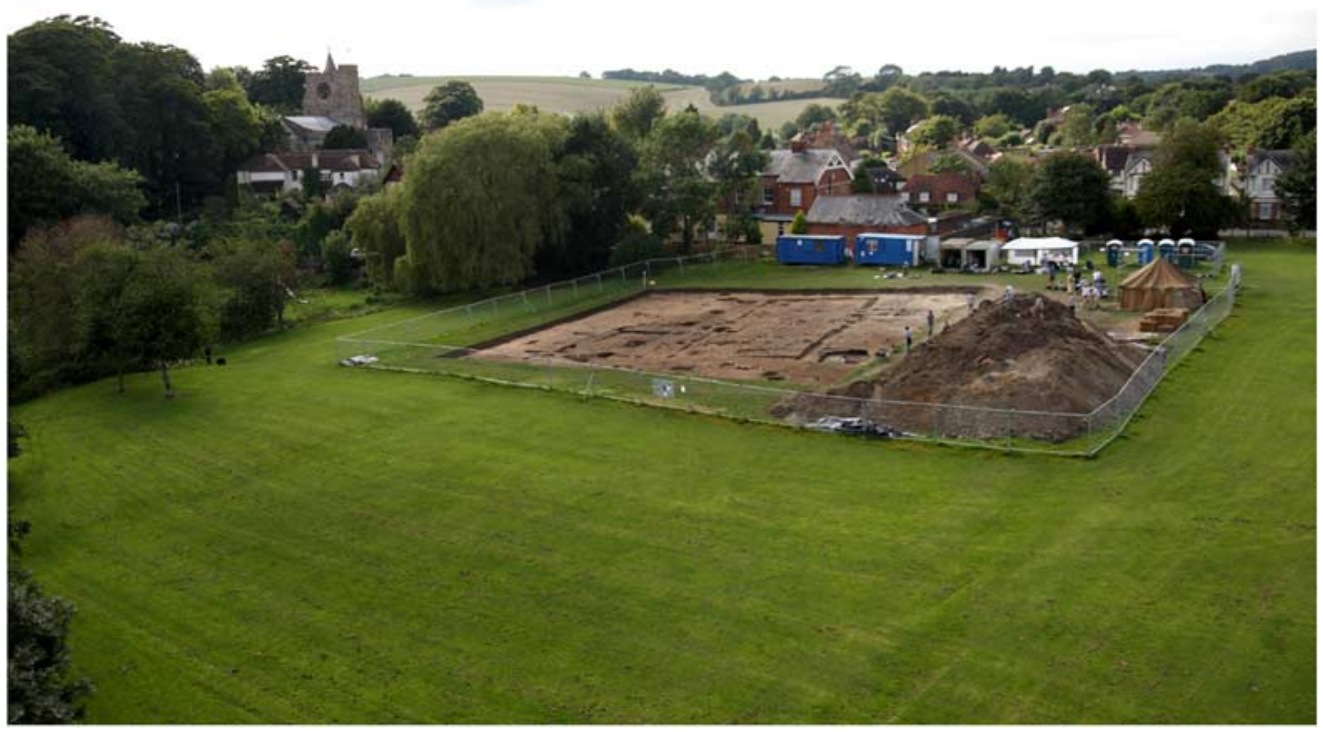

Fig 9. View across Tayne Field looking south west, with the 2012 excavation trench in the foreground and the chalk promontory capped by the parish church beyond. The line of trees to the left of the excavation marks the course of the River Nailbourne, which emerges from a spring to the left of the large weeping willow. Photograph: Hawkeye Elevated Photography

up of paired timber planks set in parallel alignment at regular intervals, the gaps being infilled with wattle-and-daub panels. The foundations of the long walls were interrupted by substantial post-pits marking the position of opposing central doorways, the southern one displaying evidence of having been replaced while the building was still in use. The recovery of a smaller post-in-trench structure on an axial alignment to the east demonstrates that this hall probably formed part of a formally planned suite of high-status buildings of the type characterising royal/aristocratic complexes at Yeavering, Sutton Courtenay and Cowdery's Down. ${ }^{67}$ For now, the hall's construction can be dated by reference to residual artefacts incorporated into the fills of its construction trenches, including diagnostic vessel glass (Fig 7) and a gilt copper-alloy bridle fitting decorated with Style I ornament attributable to $\mathrm{AD} 525^{-75}$ (Fig 8). ${ }^{68}$ There is nothing in this assemblage to suggest a date later than $\mathrm{AD} 700$, and a date before $\mathrm{AD} 650$ seems most likely, an estimation to be tested by future radiocarbon dating.

The continuous sequence of development established by these two excavations mirrors that of other broadly contemporaneous royal/aristocratic complexes: the construction of a suite of formal high-status buildings within the confines of an ancestral settlement

67. Reynolds 2003, I04-IO; Hamerow 2012, I02-5.

68. Dickinson et al 2006. I should like to thank Tania Dickinson and Chris Scull for discussing this piece with me. 
dating back to the migration period. ${ }^{69}$ More detailed correspondences between Lyminge and these cognate sites may well emerge with future excavation, but for present purposes it is appropriate to highlight one significant difference: whereas under excavation these other sites yielded very few artefacts, the great hall complex at Lyminge has produced a comparative abundance of cultural material, including significant assemblages of vessel glass, ceramics and animal bone, offering a new perspective on the nature of aristocratic social behaviour in later sixth-century Kent complementary to that hitherto provided by the mortuary arena. ${ }^{70}$

\section{A MINSTER IS FOUNDED: TRANSFORMATIONS IN THE MONASTIC-PHASE ARCHAEOLOGY OF LYMINGE}

The extensive area of the village sampled by recent excavations demonstrates that a major spatial rupture occurred in the Anglo-Saxon occupation sequence during the second half of the seventh century AD. Occupation contemporary with Lyminge's documented existence as an Anglo-Saxon monastery (ie, from the late seventh to the ninth century, dated by reference to coinage, diagnostic portable artefacts and a single radiocarbon determination) is confined to the slopes of a chalk promontory whose northern extremity, now surmounted by the parish church, was previously occupied by the core buildings of the Anglo-Saxon monastery (Fig I). The dating, character and location of this Middle Saxon occupation combine to suggest that it may be reasonably interpreted as an integral component of the AngloSaxon monastic complex, the archaeological attributes of which are discussed below.

It can be said with some degree of certainty that the westwards shift to more elevated ground was directly linked to the abandonment of the long-established valley-bottom focus, for this locale has failed to produce any conclusive evidence for Middle Saxon occupation. Although the shift was very localised in spatial terms, the topography of the two sites - the earlier low lying and in close proximity to the source of the River Nailbourne, and the later segregated through prominence - offers a very strong contrast (Fig 9). The latter setting perfectly describes the predilection of Anglo-Saxon minsters, and double houses in particular, to be founded on headlands and islands rising above the surrounding floodplain. ${ }^{7 \mathrm{I}}$ In a generic sense, such elevated sites may well have been favoured by monastic founders for their symbolic allusions to sacred Christian geography. ${ }^{72}$ But in the case of Lyminge and other places where monastic communities were implanted directly within the ceremonial foci of royal vills, a more relevant factor may have been a desire to 'maintain monastic detachment from worldly affairs'. ${ }^{73}$

The character and spatial organisation of the re-founded settlement can be determined with a reasonable degree of clarity by reference to the results of excavations to the south of the churchyard, embracing the grounds of the adjacent 'Old Rectory', and trial trenching in a bordering strip of land to the west (Fig 3). This work mapped a discontinuous swathe of Middle Saxon occupation characterised by pit clusters, boundary ditches and structural

69. Scull I991; Hamerow et al 2007, I83-9I.

70. For the comparative cleanliness of high-status compounds, see Hinton 2005, 7I-3; Blair 2005, 276; Loveluck 2009, I46.

71. Gilchrist I994, 65-9; Blair 2005, I93.

72. Blair 2005, I9I-3; Pickles $201 \mathrm{I}$.

73. Morris I989, II 8 . 


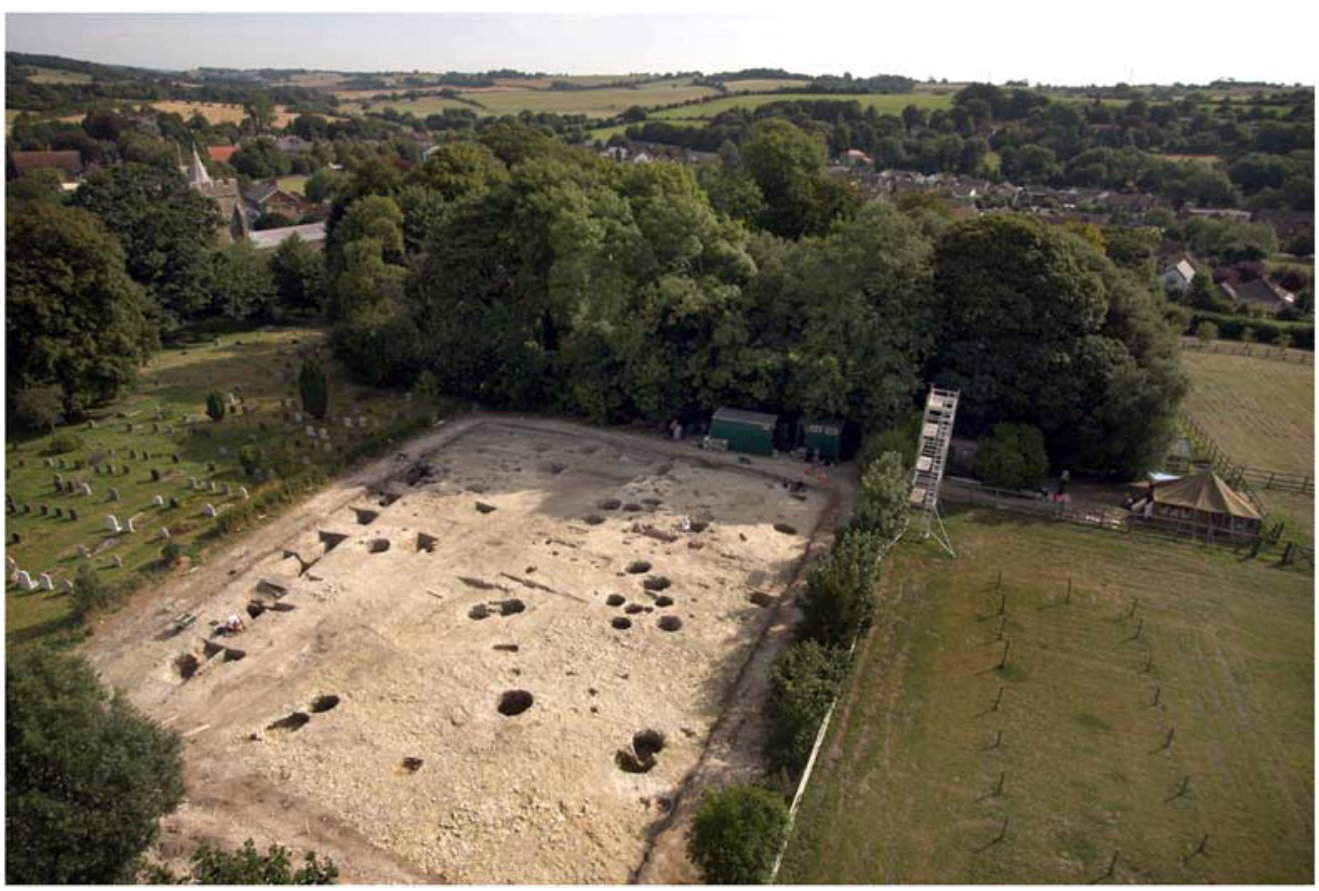

Fig IO. View across the 2009 trench (which sampled a portion of the domestic sector of the Anglo-Saxon monastic precincts) looking north east, framed by the cemetery and the grounds of the Old Rectory to its right. An internal precinct boundary can be seen under excavation at the extreme left, with clusters of latrine pits and posthole alignments provisionally interpreted as putative timber 'cells'.

Photograph: Hawkeye Elevated Photography

remains, whose southern limits can be estimated to extend some $150 \mathrm{~m}$ beyond the monastic nucleus. It may be noted that the total area thus described, measuring some 200m north-south and perhaps as much as I8om east-west, falls within the typical size range of Anglo-Saxon minster enclosures. ${ }^{74}$

The outer precinct carries clear evidence for a formalised layout expressed in a hierarchy of boundary features combined with functional zoning reflected in contrasts in building type and cultural/bioarchaeological signatures recovered from some of the pits. On this basis, a distinction can be made between an inner zone of domestic habitation, immediately to the south of the boundary of the churchyard, and an outer sector reserved for agricultural processing and industrial activities. The former appears to have encroached upon a major boundary running from north east to south west, traced for a distance of $25 \mathrm{~m}$ at the northern extremity of the 2009 excavation trench (Fig 3). The ditch had been purposefully infilled towards the end of its life, with dense concentrations of domestic refuse, and it was subsequently intercut by a concentration of pits. The spatial significance of this boundary is difficult to determine since the area to its north is occupied

74. Blair 2005, I98; Reynolds 2003, II6. In spite of extensive archaeological mapping, no clear evidence for an outer precinct boundary (vallum monasterii) has emerged. All the major boundaries appear to be related to the internal spatial organisation of the monastic precincts. 


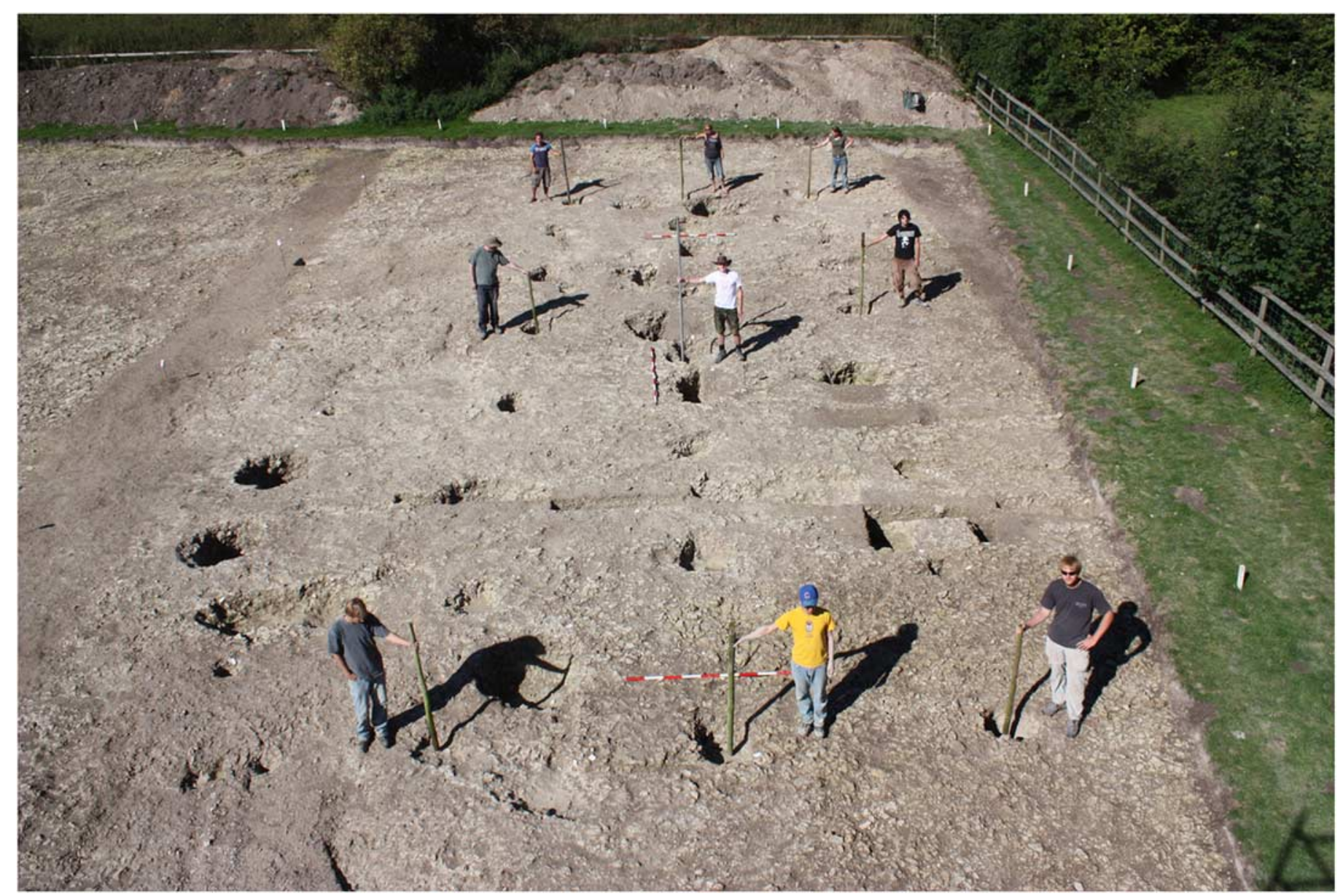

Fig II. View looking westwards down the long axis of the putative Middle Saxon granary excavated in 2008. Photograph: author 
by the modern churchyard, ${ }^{75}$ but it nevertheless provides important evidence for dynamic changes in the organisation of the monastic settlement over time. On the basis of its primary stratigraphical position, the boundary could well have been associated with the initial demarcation of the monastic nucleus, an event that can be independently dated by reference to a radiocarbon sample from the primary filling of the ditch: SUERC-35934, I29I $\pm 20 \mathrm{BP}$, cal AD 660-780 (95\% probability).

Space within the encroaching phase of domestic occupation was articulated by a perpendicular framework of timber palisades, suggesting a rectilinear layout for the overall settlement during its eighth- to ninth-century floruit. ${ }^{76}$ Beside the boundary features, the main archaeological elements of the domestic sector included a concentration of diminutive rectangular timber halls, displaying affinities with the domestic 'cells' characterising some pre-Viking monastic settlements, ${ }^{77}$ and zoned pit clusters used for managed disposal of human cess, kitchen waste and other domestic refuse (Fig I0). ${ }^{78}$

Two major economic activities are attested in the outer periphery of the Middle Saxon monastic precinct. The first, the management of agricultural surplus, is represented by a large east-west timber building with an associated metalled yard, interpreted as a granary with an exterior threshing floor (Fig II). ${ }^{79}$ The second, ironworking, is attested by a manufacturing site identified some I5Om north west of the monastic nucleus (Fig I). This was discovered in a trial trench investigating a large geophysical anomaly subsequently confirmed to be an extensive spread of smithing and smelting slag. This deposit was associated with a concentration of pits, some containing fuel ash and evidence for in situ burning, and others fragmented iron objects, predominantly knife blades, that can reasonably be attributed to on-site manufacture. ${ }^{80}$

75. The churchyard has expanded considerably since Canon Jenkins's excavations of the I850s, to the extent that the southern boundary now lies some $60 \mathrm{~m}$ south of its position as recorded on the First Edition Ordnance Survey. As a result of this encroachment it is very difficult to know how this portion of the Anglo-Saxon monastic precinct was utilised. Two interventions, both small in scale, have taken place within this sector of the churchyard in recent years: the first in I992 under the direction of Paul Bennett in response to an application for the construction of a parish office, and the second in 2007 during the inaugural year of the current programme of research. Whilst the latter produced evidence for a post-built structure of potential AngloSaxon construction (no direct dating evidence was found), the former was archaeologically sterile. It seems likely that a significant proportion of this area was given over to the monastic cemetery in the light of space restrictions to the north of the core buildings.

76. Rectilinear layouts are shared by a wide range of Anglo-Saxon settlements. For general discussions of the phenomenon, see Reynolds 2003, II9-28; Hamerow 20I2, 73-8; for specific reference to monastic planning, see Blair 2005, I96; Carver 2009, 336.

77. Loveluck 200I, IIO-II; Blair 2005, 203; Daniels 2007, 69-73.

78. The significance and potential social connotations of pits on Middle Saxon rural settlements is considered by Thomas 2010a, 207-10.

79. The structural attributes of the building are summarised in Thomas 2010b. Hamerow (2012, 50-2) discusses close structural analogies from the sites of Yarnton (Oxon) and Higham Ferrers (Northants), similarly interpreted as Middle Saxon barns/granaries.

80. The evidence is considered in assessments by Keys $201 \mathrm{I}$ and Ottaway 2012. Electronic Sawyer, Si2, demonstrates that iron was being actively exploited at Lyminge in its immediately pre-monastic phase as a royal vill (Kelly 2006, I05). Excavations in the I990s at Christ Church College by the Canterbury Archaeological Trust (Hicks and Bennett 1994) produced comparable evidence for Middle Saxon iron production in the outer precincts of St Augustine's Abbey. These discoveries clearly have great potential to inform an understanding of ironworking as a specialised component of the monastic economy of Anglo-Saxon Kent. For a discussion of comparable evidence for ironworking on early medieval monastic precincts outside Kent, see Blair 2005, $258 \mathrm{n} 60$; Kerr et al $(2012,35)$ provide an Irish perspective on the same theme. 
Overall, the Middle Saxon occupation at Lyminge provides the first detailed view of the spatial organisation of the outer precinct of an Anglo-Saxon Kentish double monastery. To some extent this image conforms with the conclusions of wider syntheses that such zones were largely 'open, and occupied by low-level industrial and agricultural activity or kitchen gardens', ${ }^{81}$ a characterisation that could equally be applied to the outer courts of later medieval nunneries. ${ }^{82}$ On the other hand, Lyminge demonstrates that such outer expanses could include more densely occupied pockets of domestic habitation and, further, that such pockets could themselves be located at a considerable distance (in this instance some $80-$ Ioom) from the core buildings. ${ }^{83}$

\section{TRANSFORMATIONS IN DIET AND THE EXPLOITATION OF ANIMAL RESOURCES}

Having examined aspects of spatial organisation and the built environment, we next turn to the rich abundance of bioarchaeological evidence from Lyminge to provide a deeper awareness of how daily social practices changed under the influence of monastic foundation. Zooarchaeological research has played a formative role in the development of more nuanced, socially informed approaches to the examination of Anglo-Saxon settlements while offering its own distinctive perspective on sociocultural change in the poorly documented centuries before the Norman Conquest. Yet in spite of a proliferation of new assemblages from rural settlement excavations, there are weaknesses in the data that constrain interpretation and impede further progress. As we have seen, few good-quality datasets exist for documented monastic institutions of the pre-Viking era; consequently our understanding of the diet and animal economy of ecclesiastical institutions remains very poorly defined in comparison to other categories of contemporary settlement, most notably Middle Saxon wics. ${ }^{84}$ Undoubtedly the most important site-based zooarchaeological synthesis for a rural settlement of the period is Flixborough, a site whose character and function remains uncertain and contested. ${ }^{85}$ Improved data coverage for known monasteries would help to put Flixborough and other central places of the seventh to ninth centuries $\mathrm{AD}$ into better zooarchaeological context and provide a clearer indication of the extent to which religious communities of this period really were distinct in terms of the way in which they consumed and produced animal resources.

Lyminge is particularly well placed to plug the gap in the Anglo-Saxon zooarchaeological record. The Middle Saxon faunal assemblage is the largest yet recovered from a major documented monastic institution of the pre-Viking period and it was generated by a rigorous and consistently applied sampling regime. Moreover, the chance to compare this assemblage with substantial collections of vertebrate remains derived from the early Anglo-Saxon settlement focus offers an unprecedented opportunity for tracking diachronic changes in diet, economic regime and human-animal relations between the later fifth and the later ninth centuries $\mathrm{AD}$. Lyminge thus represents one of the few sites with the capability to address important questions concerning how the linked processes of

8I. Blair 2005, I99.

82. Gilchrist I994, 82-5.

83. A similar point is made by Loveluck (200I, I09) in relation to other regions of Anglo-Saxon England.

84. Holmes 20II, I83.

85. Dobney et al 2007. 
Table I. Proportion of fish species by collection method (data from eighth- and ninth-century contexts excavated in 2008, after Reynolds 201 I)

\begin{tabular}{|c|c|c|c|}
\hline Species & $\begin{array}{c}\text { Hand-collected/ } \\
\text { dry-sieved }\end{array}$ & $\begin{array}{c}\text { Environmental } \\
\text { samples }\end{array}$ & Total \\
\hline Anguilla anguilla (eel) & 3 & $24 \mathrm{I}$ & 244 \\
\hline Clupea harrengus (herring) & 9 & 88 & 97 \\
\hline Clupeidae (Herring family) & o & 6 & 6 \\
\hline Conger conger (conger eel) & 4 & I & 5 \\
\hline Gadidae (Cod family) & 9I & 6 & IOI \\
\hline Gadus morhua (cod) & 576 & I6 & 588 \\
\hline Heterosomata (flatfish order) & II & $\circ$ & II \\
\hline Labrus bergylta (ballan wrasse) & 7 & 3 & Io \\
\hline Melanogrammus aegelfinus (haddock) & II & o & II \\
\hline Melanogrammus aegelfinus? & I & o & $\mathbf{I}$ \\
\hline Merlangius merlangus (whiting) & 57 & 57 & 114 \\
\hline Pagellus bogaraveo (red sea bream) & 97 & 34 & I3I \\
\hline Perciforme (perch order) & 2 & 0 & 2 \\
\hline Pleuronectidae (plaice/flounder) & I 28 & I5 & $\mathbf{1 4 3}$ \\
\hline Pleuronectidae? & 2 & 0 & 2 \\
\hline Rajdae (Ray family) & 4 & I4 & I8 \\
\hline Scomber scombrus (Atlantic mackerel) & 46 & 39 & 85 \\
\hline Scophthalmus maximus (turbot) & I & 0 & $\mathbf{I}$ \\
\hline Scophthalmus maximus? & I & 0 & $\mathbf{I}$ \\
\hline Sea bream family & I & o & $\mathbf{I}$ \\
\hline Sea bream family? & 9 & o & 9 \\
\hline Sea bass family & 6 & 0 & 6 \\
\hline Trachurus trachurus (horse mackerel) & 75 & 67 & $\mathbf{I 4 0}$ \\
\hline Trachurus trachurus? & 2 & 0 & 2 \\
\hline Trigilidae (Gurnard family) & I5 & 4 & I8 \\
\hline Total & 1159 & 591 & $\mathbf{I 7 4 7}$ \\
\hline
\end{tabular}

Christianisation and monastic foundation altered attitudes to the consumption and exploitation of animal resources in Anglo-Saxon society.

The following discussion represents a provisional examination of Lyminge's zooarchaeological potential based upon assessments of material collected between 2008 and $2010 .{ }^{86}$ It concentrates on three types of vertebrate 'signature' - fish, bird and large domesticate - to demonstrate site-based temporal change, and contextualises these diachronic trends by referring to results of recent key studies in early medieval zooarchaeology.

\section{A turn to the sea: diachronic trends in fish signatures}

Current zooarchaeological models propose that patterns of fish exploitation changed markedly over the course of the Anglo-Saxon era. It is argued that during the early

86. These assessments were produced according to relevant English Heritage guidelines: Campbell et al $20 \mathrm{II}$. 
Anglo-Saxon period the trapping of freshwater and migratory species in fish weirs in rivers and coastal estuaries represented the dominant procurement strategy. ${ }^{87}$ From the ninth century $\mathrm{AD}$, certain high-status rural settlements record a new emphasis on marine fishing as part of a more general intensification of the consumption of wild species amongst elite society. ${ }^{88}$ This development foreshadowed the 'fish event horizon' at the turn of the first millennium $\mathrm{AD}$ when marine fish were first exploited on a widespread basis as a traded food commodity. ${ }^{89}$

The prodigious quantities of fish bone recovered from recent excavations at Lyminge, provisionally estimated to number in the tens of thousands, permits the first systematic site-based examination of the dynamics of Anglo-Saxon fish consumption within a monastic context. Although the analysis is at a preliminary stage, a clear and consistent diachronic trend is apparent when the fish assemblages from the two Anglo-Saxon settlement foci are compared: a dramatic intensification in the exploitation of marine species. In the eighth-/ninth-century collection, bones of larger marine fish of the Gadidae family (principally cod and whiting) form as much as an estimated one-third of the total handcollected/dry-sieved zooarchaeological assemblage, whereas the total declines to just 3 per cent in the deposits from sixth- and seventh-century settlement contexts. Although taphonomic factors may accentuate the difference between the two periods of AngloSaxon occupation, it is safe to conclude that marine fish were being consumed at a more intense level in the eighth and ninth centuries and that their dietary contribution at this period was significant. ${ }^{90}$

To what extent can this temporal shift be considered a revolutionary development triggered by the specific dietary needs and provisioning networks of a monastic establishment? It is possible to make some progress towards answering this question by considering smaller fish taxa recovered from environmental bulk samples (Table I). This element is well represented in heavy residues from both sixth- and seventh-century contexts and those of the eighth and ninth centuries, in the former case totalling as much as 35 per cent of the recorded taxa from SFB2. ${ }^{91}$ An assessment of the sixth- and seventh-century component demonstrates that marine species (herring followed by plaice/flounder) heavily outnumber eel and cyprinids, which together make up less than Io per cent of the total identifiable assemblage. ${ }^{92}$ Fish procurement at Early Saxon Lyminge was evidently focused upon coastal inshore and estuarine environments, with very limited exploitation of nearby rivers and streams. ${ }^{93}$ The implication is that the upsurge in the consumption of marine fish seen in the eighth and ninth centuries represents not so much a radical departure from what had

87. Serjeantson and Woolgar 2006, I03.

88. Sykes $2007,57-8$, figs $56-7$.

89. Barrett et al 2004 .

90. The extent to which different contexts of discovery (sunken-featured buildings on the one hand, pits and ditches on the other) may have influenced this temporal distinction in the handcollected fish bone is an interesting question deserving of further enquiry. Intensification in the exploitation of coastal resources is also registered in a much greater abundance and diversity of marine mollusca in eighth- and ninth-century contexts.

91. Data quoted in Baker 20I2, 7, referencing an assessment of the 2010 environmental bulk samples in Campbell 2012.

92. The relevant data is assessed in Reynolds 2013.

93. This conclusion is somewhat surprising given that the neighbouring settlement of Elham bears an obvious toponymic reference to eel fishing in the Anglo-Saxon period; see Wallenberg I934, 43I. 


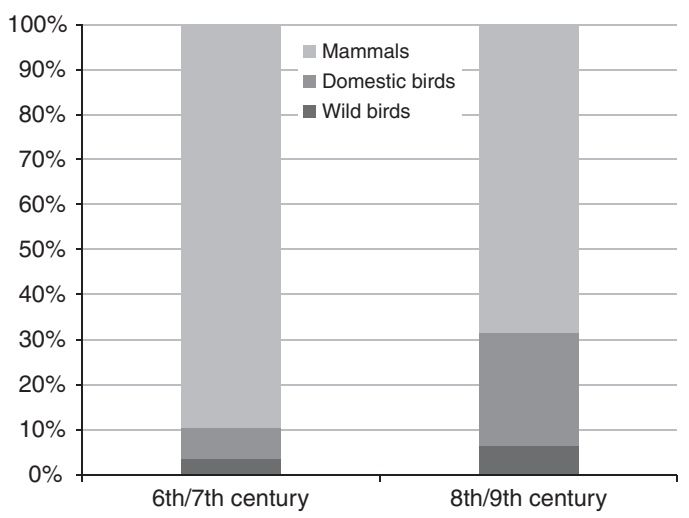

Fig I2. Inter-period variation in bird taxa based on rounded proportions of handcollected/dry-sieved bone from assessed feature contexts. The category 'Mammals' is restricted to cattle, sheep and pig. Data: from Baker 2012, tables 2, 4 and Io

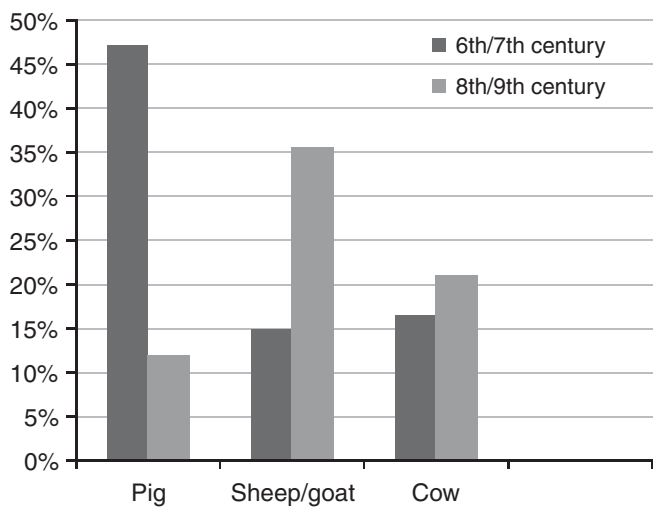

Fig 13. Inter-period variation in main domesticated animal taxa based on rounded proportions of hand-collected/dry-sieved animal bone from assessed feature contexts. Data: from Baker 2012, tables 2, 4 and Io

gone before as a reorientation: a diversification in the exploitation of coastal resources, placing new emphasis on deep-water Gadidae but with a continued level of investment in inshore/coastal estuarine species.

Very few rural settlements of the early Anglo-Saxon period, even those with relatively convenient coastal access, produce fish bone in any significant quantity. ${ }^{94}$ Lyminge's sixth- and seventh-century assemblage, although small in comparison to its Middle Saxon phases, should therefore be viewed as an additional indicator of its social status as a district centre exercising a gravitational pull over outlying resources. But how should we contextualise the much larger Middle Saxon assemblage? Lyminge joins a select number of seventh- to ninth-century $\mathrm{AD}$ rural settlements that register an emphasis on marine

94. Dobney et al 2007, 228-9. 
fishing well before the hypothesised fish event horizon of $c \mathrm{AD}$ Ioo०. Without exception, these sites are coastal in location or, like Lyminge, enjoyed relatively convenient coastal access. ${ }^{95}$ Two of these comparanda are located on the south coast in reasonably close proximity to Lyminge: Sandtun, arguably a satellite actively involved in provisioning the monastic community at Lyminge itself, and Bishopstone, in neighbouring East Sussex, a settlement of demonstrably high-status character occupied between the eighth and tenth centuries AD. ${ }^{96}$

Historical sources provide their own perspective on the pioneering role played by monastic institutions in the move towards more intensified forms of fishing. Indeed, one of the key strands of supporting evidence - the granting of coastal fisheries to inland monasteries - is directly attested in the Anglo-Saxon charter record for Lyminge, specifically in relation to its piecemeal acquisition of lucrative landholdings on Romney Marsh. A fishery on the River Lympne is explicitly recorded in a donation of $\mathrm{AD} 74 \mathrm{I},{ }^{97}$ whilst archaeological evidence demonstrates that the coastal property of Sandtun, granted to Lyminge in $\mathrm{AD} 732$, was actively engaged in marine fishing as an economic complement to salt production and cross-channel trade..$^{98}$

\section{Diachronic trends in bird and domestic animal signatures}

A further diachronic trend that may be noted is a rise in the proportion of bird taxa from an extrapolated Io per cent in sixth- and seventh-century contexts to as much as 33 per cent in those of the eighth and ninth centuries. Significantly, this increase is accompanied by a taxonomic shift in the ratio of wild to domesticated species, with the former declining from just under one-third of the total bird assemblage from sixth- and seventh-century contexts to only one-fifth of the eighth- and ninth-century assemblage (Fig I2). ${ }^{99}$ The indication is that domesticated bird species, chiefly chicken and, to a lesser extent, goose and duck, were exploited at a much greater level of intensity during the monastic phase of occupation than had been the case in earlier centuries.

This pattern may be contextualised by referring to recent zooarchaeological studies examining bird signatures from Anglo-Saxon settlements. This research highlights a tendency for ecclesiastical sites of the Middle Saxon period to exhibit a more restricted range of wild bird taxa than contemporary secular estate centres, the latter being characterised by greater species diversity, including raptors and such exotics as black grouse procured through the elite activity of hunting. ${ }^{\text {Ioo }}$

95. Barrett et al 2004, 62 I-2.

96. For discussion of the relevant assemblages, see Hamilton-Dyer 200I; Reynolds 20I0. Although conceptualised by some as an Anglo-Saxon minster, the occupation represented at Bishopstone is open to a secular interpretation; for contrasting viewpoints, see Blair and Pickles 20Io; Thomas 2010a, 213-16.

97. Electronic Sawyer, S25.

98. Electronic Sawyer, S24. Kelly (2006, I I I) proposed Lympne as an alternative monastic recipient of the Sandtun estate but has since revised her interpretation in favour of Lyminge (Nicholas Brooks, pers comm). The archaeological evidence from Sandtun is discussed by Gardiner et al 2001.

99. Data quoted in Baker 2012, 7.

IOO. Dobney and Jaques 2002; Dobney et al 2007, 224-7. Synthesis of zooarchaeological assemblages from monastic houses in early medieval Normandy (Sykes 2007, 19) indicates a similar emphasis on domestic fowl. 
As a final illustration of diachronic trends in the faunal assemblage one can point to a clear shift in the relative importance of larger domesticated animals. ${ }^{\text {IOI }}$ The main domesticate represented in sixth- and seventh-century contexts is pig, which constitutes some 45 to 55 per cent of assessed assemblages. Many zooarchaeologists recognise elevated proportions of pig (30 per cent and higher) as a high-status dietary signature during the Anglo-Saxon period, and pork appears to have enjoyed widespread social connotations as a food of conspicuous consumption across broad swathes of early medieval France, Belgium and Rhineland Germany. ${ }^{\text {I02 }}$

The animal-bone assemblage from eighth- and ninth-century occupation tells a very different story. In this period the proportion of sheep increases from is per cent in the sixth and seventh centuries to between 36 and 54 per cent in assessed contexts dating from the eighth and ninth centuries at the expense of pig, which declines significantly, ranging from 12 to 27 per cent in assessed contexts (Fig I3).

This shift accords with wider evidence for an increase in the relative importance of sheep between the Early and Middle Saxon periods. ${ }^{\text {IO3 }}$ By comparing species ratios, body-part distributions and age profiles across a broad range of Early and Middle Saxon rural settlements, Crabtree argued that this temporal trend was linked to the introduction of new husbandry practices specifically geared towards specialised wool production. Explanatory models of economic change in Middle Saxon England have hitherto placed major emphasis on the expanding populations of wics as a trigger for rural intensification. One of the important implications raised by the expanded body of zooarchaeological data examined by Crabtree is that 'monastic sites and rural estate-centres should be seen as agents of innovation in agriculture and animal husbandry in the early Middle Ages'. ${ }^{\circ} 4$ Detailed analysis of the faunal assemblages must be completed before it can be said with certainty that the sheep remains represented at Lyminge reflect the intensive management of flocks reared for their wool, but existing evidence - most notably, abundant assemblages of textile manufacturing equipment from eighth- and ninth-century contexts - points strongly in this direction. ${ }^{\text {IO5 }}$

\section{Discussion}

The temporal patterning highlighted in the foregoing discussion indicates that Lyminge will be able to fulfil its potential as a baseline zooarchaeological assemblage for exploring how the exploitation and perception of animals in Anglo-Saxon society changed during the Conversion period under the impetus of monastic foundation and the wider process of Christianisation. Evidence adduced from both the archaeology and Anglo-Saxon charters indicates that coastal landholdings on Romney Marsh played a pivotal role in supplying the monastic community at Lyminge with food and animal resources; moreover, it may be the case that the very acquisition of these estates acted as a stimulus for innovations

IOI. Both NISP (number of identified specimens present) and quantification by body part were undertaken to avoid biases in particular skeletal element groups; the data therefore indicates a real change in site diet, economy or husbandry practice (Baker 2012, I0).

I02. Dobney et al 2007, 238-40; Loveluck 2009, I50-I.

I03. Crabtree 2010.

I04. Ibid, I33.

I05. As represented by an abundance of textile-manufacturing equipment ranging across bunshaped loom weights, bone needles, pin-beaters and spindle whorls. 
in animal husbandry techniques and marine fishing. ${ }^{\text {I06 }}$ Provisional though they are, the indications are that Middle Saxon Lyminge, in spite of its inland location, was distinguished by a strongly marine-orientated culture and economy.

A natural question raised by Lyminge's Middle Saxon animal-bone assemblage is the extent to which the relatively high proportions of fish and fowl might be a product of monastic food regulations and fasting. This question is very difficult to answer at the current stage of understanding. Before the Benedictine Rule was first codified in the tenth century, Anglo-Saxon monastic communities were governed by a diversity of rules and there is no historical certainty about how Kentish double houses fit into the spectrum. ${ }^{107}$ Gaps in the historical record also leave us ignorant of what types of food were accepted and prohibited during periods of fasting in the liturgical calendar, as a consequence of which we are poorly informed on the role of fish in the early medieval Christian diet. ${ }^{\text {IO8 }}$ Bereft of contextual sources of information, excavated animal-bone assemblages must be made to do the work of interpretation and, as Ervynck and others have shown, this work is burdened by several interacting complexities: on the one hand, issues of modern recovery/sampling bias, and, on the other, historically contingent factors governing how monastic rules operated on a daily basis at different times and places. ${ }^{\text {I09 }}$ Nevertheless, one point made clear by recent research conducted on monastic animal-bone assemblages from Anglo-Saxon England and neighbouring regions of the British Isles is that the ascetic dietary regimes portrayed within contemporary hagiography bear very little relation to the realities of daily life within contemporary monastic institutions, where meat appears to have been consumed on a not irregular basis. ${ }^{\text {IIO }}$

A key point raised by Ervynck is that 'real proof [for meat abstinence] could only be found when it could be demonstrated that monastic sites consistently yield much higher frequencies of fish bones compared to contemporaneous non-monastic sites from the same region'. II Needless to say, we are a long way from reaching this stage of understanding in the dimly lit world of pre-Viking Kent and the temptation to interpret Lyminge's faunal assemblage with specific reference to the Benedictine Rule must therefore be resisted. On the other hand, research conducted in other regions of England has begun to identify distinctions in species representation between monastic sites and contemporary high-status secular settlements in the Middle Saxon period, the former being characterised by higher proportions of fowl and sheep and lower proportions of wild birds and mammals than the latter. ${ }^{\mathrm{II} 2}$ On the basis of the patterning seen elsewhere, one could certainly argue that Lyminge registers a strong 'monastic' vertebrate signature, but

I06. For a detailed discussion of the Anglo-Saxon charters pertaining to Lyminge's Romney Marsh estates, see Brooks I988. As revealed in a recent historical survey by Lebecq (2000), coastal salt marsh was equally central to the economics of monastic landholding in early medieval northern Frankia.

I07. Foot 2006, 48-69.

108. Barrett et al 2004, 629; Serjeantson and Woolgar 2006, I04.

I09. Ervynck 1997, 7I-3.

IIO. Murray et al 2004; Dobney et al 2007, 220; Huntley and Rackham 2007, I2I. Within the strictures of the Benedictine Rule, sick brethren were permitted to eat meat; other factors, however, are equally relevant to the interpretation of these meat-rich assemblages, not least the fact that, as Foot has observed $(2006,236)$, 'feasting and its necessary accompaniment, drinking, were as much a part of monastic life as they were central to contemporary aristocratic culture'.

III. Ervynck 1997, 75.

II2. Holmes (20II, I83-4) draws attention to this distinction in a recent synthesis of zooarchaeological assemblages from Anglo-Saxon England. Cramp (2005, 343-4) notes that the earliest 
full analysis of the assemblage, taking into account finer spatio-temporal distinctions, must be conducted before the deeper meanings of this signature can be more fully understood in its regional and national context.

\section{CONCLUSIONS}

As a form of emplacement, Anglo-Saxon monastic foundations could follow many different trajectories, but common to all was a dialogue with meaningful places that formed the bedrock of the host community's sense of identity and collective social memory. Lyminge gives insight into one particular path of emplacement that saw certain monastic foundations established at nodal points in Anglo-Saxon topographies of power: the ceremonial and domestic epicentres of royal vills. Historical sources, pre-eminently Bede's Ecclesiastical History, testify to this kind of appropriation by drawing attention to instances where, in the ultimate embodiment of kingly largesse towards the new Christian faith, royal vills were expressly granted for the purpose of monastic foundation. ${ }^{\text {II } 3}$ While such scenarios have hitherto been imagined through the prism of textual evidence, Lyminge now provides a concrete archaeological visualisation of how that process occurred on the ground with reference to the unfolding biography of a Kentish district centre.

Three general points can be drawn from this visualisation by way of conclusion. First, monastic foundation at Lyminge appears to have followed close on the heels of a programme of monumentalisation reflected in the construction of a great hall complex $c \mathrm{AD}$ 600-50, a complex itself 'emplaced' within the confines of an ancestral settlement dating back to the fifth century AD. Monastic foundation can thus be seen as a secondary stage in the royal appropriation of a site of long-standing social and religious significance whose origins were rooted in the emergent power structures of sixth-century Kent. The beginnings of this sequence pose interesting questions about the character of central places in early Anglo-Saxon Kent in the period before the rise of the historically attested kingdom in the closing decades of the sixth century. As argued for other regions of Anglo-Saxon England, the evidence from Lyminge indicates that expressions of power at this early date are not reflected in monumental settings and/or buildings of the type characterising the domestic/ceremonial component of central places in early medieval Scandinavia. ${ }^{\text {II } 4}$ Yet, as demonstrated by the wealth buried in Lyminge's two cemeteries, now joined by expressions of conspicuous consumption in contemporary settlement deposits dating to the sixth century, this distinction should not diminish our estimation of the ability of early Anglo-Saxon lineages to reproduce power through the control of places resonant with potent ancestral and cosmological meanings. ${ }^{\text {II5 }}$

Second, the character and trajectory of Lyminge as a central place changed decisively during the closing decades of the seventh century, when the historical sources attest that it emerged with a new identity as a royal double monastery. The process of monastic

phases of monastic activity at Anglo-Saxon Jarrow are defined by a preponderance of fowl, fish and sheep, with Hartlepool offering a close Northumbrian comparison.

II3. Morris 1989, I3I-2; Blair 2005, I86-7. This form of appropriation has a long ancestry in the annals of the early Christian Church in the West; for relevant discussion, see Blair 2005, 38-9; Percival 1997. I should like to thank Rosemary Cramp for reminding me of this long-term context. II4. Williams 2002.

II5. Carlton Colville (Suff) is a further Anglo-Saxon settlement demonstrating similarly early expressions of a central-place role (Lucy et al 2009, 430-4). 
emplacement appears to have been mediated by a re-siting of the settlement from what had been its long-established ancestral focus, recently aggrandised with its suite of royal accommodation, to a new elevated location sanctified by the construction of the minsterchurch and adjacent core buildings - a new locus of social action that was to endure for the next 200 years. ${ }^{\text {II6 }}$ This clear evidence for a major reconfiguration of space within the Anglo-Saxon occupation sequence can be conceptualised as the conscious creation of a new sacred topography, one that rechannelled the powerful cult associations of Lyminge's pagan past into a Christianised landscape setting amenable to the practical and symbolic needs of what started life as a female-dominated monastic community.

Third, Lyminge's rich zooarchaeological assemblages hold important clues on how daily social practices changed alongside alterations to the configuration of space and the built environment. Diachronic shifts in various vertebrate signatures underline significant transformations in food supply and animal resourcing during the Anglo-Saxon occupation sequence. Lyminge as a monastic community in the eighth and ninth centuries AD was consuming marine fish and domestic fowl at a much higher intensity than it had been as a pre-Christian district centre in the sixth, while the emphasis on animal husbandry had shifted from the rearing of pigs to that of sheep. These changing patterns deserve to be understood and interrogated as more than simply a passive reflection of changing economic circumstances, but rather as a window on the active role played by monastic establishments in investing the natural world and its resources with new Christianised meanings.

In the introduction to this paper it was argued that the historical development of Anglo-Saxon settlement archaeology has created strong biases in excavated data preventing detailed comparisons between known monastic establishments and a broader category of undocumented rural habitations brought to light by commercial archaeology. Lyminge represents an ongoing experiment aimed at bridging the gap - how does a site with an unambiguous monastic pedigree behave when sampled at the scale and level of intensity accorded to high-quality commercial excavations? The opportunity to examine areas lying outside the monastery's cult focus has yielded rare evidence for a planned settlement zone surrounded by a periphery of agricultural and industrial activities offering rich insights into the daily economy and lifestyle of the monastic community. Comparable archaeological evidence available in published form has hitherto come from a small number of sites lying within the Anglo-Saxon kingdom of Northumbria: from Beverley, Hartlepool, Hoddom and Whitby. The current project has shifted the focus of academic attention to Kent, a monastic context that deserves to be better understood archaeologically on the grounds of its formative role in the earliest stages of the Anglo-Saxon Conversion and for the opportunities for interdisciplinary engagement provided by the comparatively good survival of early historical sources. Perhaps the greatest contribution this particular region can make to understanding, as this paper has attempted to highlight, is to offer fertile new archaeological territory for exploring how monastic culture and its underpinning Christian world view was assimilated into the traditional and local structures of Anglo-Saxon society - a unifying theme in the Conversion narratives of early medieval peoples across north-west Europe and the mechanism that gave rise to its myriad 'micro-Christendoms'. ${ }^{117}$

II6. The discovery of Late Saxon and Saxo-Norman occupation on Tayne Field in the 2012 excavation and in trial trenches adjacent to the village hall car park in 2010 demonstrates a subsequent settlement shift to lower-lying ground following the alignment of Lyminge High Street.

II7. Brown 1996, 216-34. 


\section{ACKNOWLEDGEMENTS}

The current (2012-I4) excavation campaign is funded by the Arts and Humanities Research Council. Post-excavation analysis of the previous excavations (2008-I0) was supported by grants from the British Academy, the Society of Antiquaries of London, the Royal Archaeological Institute and the Marc Fitch Fund. For input into the postexcavation programme, I should particularly like to thank Poly Baker and Gill Campbell at English Heritage and the following specialists working in a research/consultant capacity: Rose Broadley, Greg Campbell, Ben Jervis, Lynne Keys, FSA, Peter Marshall, Patrick Ottaway, FSA, Rebecca Reynolds and Christopher Scull, FSA. The excavations could not have happened without the generous permission of the following landowners: the RolandPaynes of the Old Rectory, Paul Tory, Janet Laing, Lyminge Parochial Church Council and Lyminge Parish Council. Of the various individuals who assisted in the field, I should like especially to thank the following core team of supervisory staff: Dan Bray, Wendy Charlton, Rosie Cummings, Alexandra Knox, Helen Harrington, John Hutchings, Simon Maslin, Roo Mitcheson, David Mudd, Gemma Watson, Rosie Weetch and Celia Winning. Excavations in 2012 benefited immeasurably from the supervisory input of Keith Parfitt, FSA, and Andy Macintosh of Canterbury Archaeological Trust. Key logistical support throughout the life of the Lyminge project has been generously provided by Neil Mullins of Little Woodlands Farm. Many Lyminge residents have given freely of their time to support the activities of the project and a greater number still have shown enthusiasm for our endeavours; I owe a deep debt of gratitude to them all. Sarah Lucas, Alexandra Knox and Simon Maslin kindly assisted in preparing the illustrations for this paper, the published version of which has benefited from critical feedback on the text by Grenville Astill, FSA, Poly Baker, Charlotte Behr, Nicholas Brooks, FSA, Rosemary Cramp, FSA, and Christopher Scull, FSA.

\section{BIBLIOGRAPHY}

Baker, P 2012. 'Assessment of the animal bone assemblage from the 2009 and 2010 excavations at Lyminge, Kent', unpublished report, 〈http://www.reading.ac.uk/web/FILES/ archaeology/AnimalBoneAssessment-Baker 20I2.pdf $>$ (4 Dec 20I2)

Barrett, J H, Locker, A M and Roberts, C M 2004. "Dark Age" economics revisited: the English fish bone evidence $\mathrm{AD}$ 600-I600', Antiquity, 78, 6I8-36

Behr, C 2000. 'The origins of kingship in early medieval Kent', Early Medieval Europe, 9, 25-52

Blair, J I992. 'Anglo-Saxon minsters: a topographic review', in Pastoral Care Before the Parish (eds J Blair and R Sharpe), 226-66, Leicester University Press

Blair, J 2005. The Church in Anglo-Saxon Society, Oxford University Press

Blair, J 20II. 'Overview: the archaeology of religion', in Hamerow et al 20I I, 727-4I

Blair, J and Pickles, T 2010. 'Bishopstone and Deantone: the estate and the church under the Mercian kings and the South Saxon bishops', in Thomas 2010a, I7-22

Bond, J 2004. Monastic Landscapes, Stroud: Tempus

Broadley, R 20II. 'Lyminge glass: assessment report', unpublished report, 〈http://www. reading.ac.uk/web/FILES/archaeology/AngloSaxon_glass_assessment_report._Broadley_ 20II.pdf $>$ (4 Dec 20I2)

Brookes, S 2007. 'Walking with Anglo-Saxons: landscapes of the dead in early AngloSaxon Kent', in Semple 2007, I43-53

Brookes, S 20I I. 'The lathes of Kent: a review of the evidence', in Studies in Early AngloSaxon Art and Archaeology: papers in honour of Martin $G$ Welch (eds S Brookes, $S$ Harrington and A Reynolds), I56-70, BAR Brit Ser 527, Oxford: Archaeopress

Brooks, N I988. 'Romney Marsh in the early Middle Ages', in Romney Marsh: evolution, occupation, reclamation (eds J Eddison and C Green), 90-I04, Oxford Univ Comm Archaeol Monogr 24, Oxford 
Brooks, N I989. 'The creation and early structure of the kingdom of Kent', in The Origins of the Anglo-Saxon Kingdoms (ed S Bassett), 55-74, Leicester University Press

Brooks, N 1996. The Early History of the Church of Canterbury, Leicester University Press

Brown, P I996. The Rise of Western Christendom: triumph and diversity $A D$ 200-IOOO, Oxford: Blackwell

Cambridge, E I999. 'The architecture of the Augustinian mission', in Gameson I999, 202-36

Campbell, G 20I2. 'Assessment of charred and mineral-replaced macroscopic plant remains from excavation at Lyminge, Kent, 2008-IO', unpublished report, <http:// www.reading.ac.uk/web/FILES/archaeology/ Campbell2or2-palaeobotanical_assessment. pdf $>$ (4 Dec 20I2)

Campbell, G, Moffett, L and Straker, V 201 I. Environmental Archaeology: a guide to the theory and practice of methods from sampling and recovery to post-excavation, 2 nd edn, London: English Heritage

Carr, R D, Tester, A and Murphy, P I988. 'The Middle-Saxon settlement at Staunch Meadow, Brandon', Antiquity, 62, 37I-7

Carver, M 2009. 'Early Scottish monasteries and prehistory: a preliminary dialogue', Scott Hist Rev, 88, 332-5I

Crabtree, P J 20I0. 'Agricultural innovation and socio-economic change in early medieval Europe: evidence from Britain and France', World Archaeol, 42 (I), I22-36

Cramp, R 2005. Wearmouth and Farrow Monastic Sites. Vol I, London: English Heritage

Daniels, R 2007. Anglo-Saxon Hartlepool and the Foundations of English Christianity: an archaeology of the Anglo-Saxon monastery, Hartlepool: Tees Archaeology

De Jong, $M$ and Theuws, F 200I. Topographies of Power in the Early Middle Ages, Leiden: Brill

Devlin, Z 2007. Remembering the Dead in AngloSaxon England, BAR Brit Ser 446, Oxford: Archaeopress

Dickinson, T M, Fern, C and Hall, M 2006. 'An early Anglo-Saxon bridle-fitting from South Leckaway, Forfar, Angus, Scotland', Medieval Archaeol, 50, 249-6o

Dickinson, T M, Fern, C and Richardson, A 20II. 'Early Anglo-Saxon Eastry: archaeological evidence for the beginnings of a district centre in the kingdom of Kent', Anglo-Saxon Stud Archaeol Hist, 17, I-86

Dobney, K and Jacques, D 2002. 'Avian signatures for identity and status in Anglo-Saxon England', Acta Zoologica Cracoviensia, 45, 7-2I
Dobney, K, Jacques, D, Barrett, J and Johnstone, C 2007. Farmers, Monks and Aristocrats: the environmental archaeology of Anglo-Saxon Flixborough, Excavations at Flixborough 3, Oxford: Oxbow

Electronic Sawyer 〈http://www.esawyer.org.uk〉 (25 Mar 2013). Online version of Peter Sawyer's Anglo-Saxon Charters: an annotated list and bibliography (I968), revised, updated and expanded by S Kelly, London: Royal Historical Society

Ervynck, A I997. 'Following the rule? Fish and meat consumption in monastic communities in Flanders (Belgium)', in Environment and Subsistence in Medieval Europe (eds G de Boe and F Verhaeghe), 67-8I, IAP Rapporten 9, Zellik: Instituut voor het Archaeologisch Patrimonium

Everitt, A 1988. Continuity and Colonization: the evolution of Kentish settlement, Leicester University Press

Evison, V 2008. A Catalogue of Anglo-Saxon Glass in the British Museum, Brit Mus Res Publ 167, London: British Museum

Fern, C 2007. 'Early Anglo-Saxon horse burial of the fifth to seventh century $\mathrm{AD}^{\prime}$, in Semple 2007, 92-I09

Foot, S 2000. Veiled Women: the disappearance of nuns from Anglo-Saxon England, Manchester University Press

Foot, S 2006. Monastic Life in Anglo-Saxon England c 600-900, Cambridge University Press

Gameson, R I999. St Augustine and the Conversion of England, Stroud: Sutton

Gardiner, M, Cross, R, Macpherson-Grant, N and Riddler, I 200I. 'Continental trade and non-urban ports in mid-Anglo-Saxon England: excavations at Sandtun, West Hythe, Kent', Archaeol F, 158, I6I-290

Gilchrist, R I994. Gender and Material Culture: the archaeology of religious women, London: Routledge

Gilchrist, $\mathrm{R}$ and Mytum, H I989. The Archaeology of Rural Monasteries, BAR Brit Ser 203, Oxford: British Archaeological Reports

Gittos, H 20II. 'Christian sacred spaces and places', in Hamerow et al 20I I, 824-44

Hall, R and Whyman, M I996. 'Settlement and monasticism at Ripon, North Yorkshire, from the seventh to eleventh centuries AD', Medieval Archaeol, 40, 62-I50

Hamerow, H 2006. 'Special deposits in AngloSaxon settlements', Medieval Archaeol, 5o, I-30

Hamerow, H 2012. Rural Settlements and Society in Anglo-Saxon England, Oxford University Press

Hamerow, H, Hayden, C and Hey, G 2007. 'Anglo-Saxon and earlier settlement 
near Drayton Road, Sutton Courtenay, Berkshire', Archaeol F, I64, I09-96

Hamerow, H, Hinton, D A and Crawford, S 20II. The Oxford Handbook of Anglo-Saxon Archaeology, Oxford University Press

Hamilton-Dyer, S 200I. 'Bird and fish remains', in Gardiner et al 200I, 255-6I

Hicks, $M$ and Bennett, P I994. 'Christ Church College', in Canterbury's Archaeology 1993-4, I-4, Canterbury Archaeological Trust

Hinton, D A 2005. Gold and Gilt, Pots and Pins: possessions and people in medieval Britain, Oxford University Press

Holmes, M 20II. 'Food, status and provisioning in Saxon and Scandinavian England', unpublished $\mathrm{PhD}$ thesis, University of Leicester

Huntley, J and Rackham, J 2007. 'The environmental setting and provisioning of the AngloSaxon monastery', in Daniels 2007, 108-23

James, S, Marshall, A and Millett, M I984. 'An early medieval building tradition', Archaeol $\mathcal{F}$, I4I, I82-2 I 5

Kelly, S 2006. 'Lyminge minster and its early charters', in Anglo-Saxons: studies presented to Cyril Hart (eds S Keynes and A P Smyth), 98-I I3, Dublin: Four Courts Press

Kerr, T, Doyle, M, Seaver, M, McCormick, F and O'Sullivan, A 2012. Industrial Activity on Rural Secular Sites in Ireland, $A D$ 400-IIOO, Early Medieval Archaeology Project (EMAP) Report 6.I, University College Dublin, 〈http://www.emap.ie/ documents/EMAP2OI2_EarIyMed_Industry_ on_Rural_Sites.pdf $>$ (I3 May 2013)

Keys, L 20II. 'Assessment of iron slag and related high temperature debris from sites in Lyminge, Kent', unpublished report, 〈http://www.reading.ac.uk/web/FILES/ archaeology/Iron_slag_assessment_report. _Keys_20II.pdf $>$ (4 Dec 20I2)

Lebecq, $\mathrm{S} 2000$. 'The role of the monasteries in the systems of production and exchange of the Frankish world between the seventh and the beginning of the ninth centuries', in The Long Eighth Century: production, distribution and demand (eds I L Hansen and C Wickham), I2I-48, Leiden: Brill

Loveluck, C P 200I. 'Wealth, waste and conspicuous consumption: Flixborough and its importance for middle and late Saxon rural settlement studies', in Image and Power in the Archaeology of Early Medieval Britain: essays in honour of Rosemary Cramp (eds $\mathrm{H}$ Hamerow and A MacGregor), 78-130, Oxford: Oxbow

Loveluck, C P 2005. 'Rural settlement hierarchy in the age of Charlemagne', in
Charlemagne: empire and society (ed J Story), 230-58, Manchester University Press

Loveluck, C P 2007a. Rural Settlement, Lifestyles and Social Change in the Late First Millennium AD: Anglo-Saxon Flixborough in its wider context, Excavations at Flixborough 4, Oxford: Oxbow

Loveluck, C P 2007b. 'Anglo-Saxon Hartlepool and the foundations of English Christian identity: the wider context and importance of the monastery', in Daniels 2007, I86-208

Loveluck, C P 2009. 'The dynamics of elite lifestyles in the rural world, AD 600-II50: archaeological perspectives from northwest Europe', in La Culture du haut Moyen Âge, Une Question d'Élites? (eds F Bougard, R Le Jan and R McKitterick), I39-70, Haut Moyen Âge 7, Turnhout: Brepols

Lowe, C 2006. Excavations at Hoddom, Dumfriesshire, Edinburgh: Society of the Antiquaries of Scotland

Lucy, S, Tipper, J and Dickens, A 2009. The Anglo-Saxon Settlement and Cemetery at Bloodmoor Hill, Carlton Colville, Suffolk, E Anglian Archaeol Rep I3I, Cambridge Archaeological Unit

Maslin, S 20I2. 'The taphonomy and micromorphology of sunken featured building fills from Lyminge, Kent; a comparative mixed-method analysis', unpublished MSc thesis, University of Reading

Morris, C 1989. Churches in the Landscape, London: Dent

Morris, C 2008. Fourneys from farrow, Jarrow Lecture 2004, Jarrow: St Paul's Church

Murray, E, McCormick, F and Plunkett, G 2004. 'The food economies of Atlantic island monasteries: the documentary and archaeo-environmental evidence', Envir Archaeol, 9, I79-88

O'Sullivan, A, McKormick, F, Harney, L, Kinsella, J and Kerr, T 20I0. Early Medieval Settlements in Ireland, AD 400-IIOO. Vol I: Text, Early Medieval Archaeology Project (EMAP) Report 4.2, University College Dublin, 〈http://www.ucd.ie/archaeology/ documentstore/allreports/emap_report_ 4.2voli_print.pdf $>$ (I3 May 20I3)

Ottaway, P 2012. 'Assessment of ironwork from the excavations 2007-2010', unpublished report, 〈http://www.reading.ac.uk/web/ FILES/archaeology/Ottaway20I2-ironwork_ assessment.pdf > (4 Dec 20I2)

Percival, J 1997. 'Villas and monasteries in Late Roman Gaul', $\mathcal{F}$ Eccles Hist, 48 (I), I-2I

Pestell, $\mathrm{T}$ 2004. Landscapes of Monastic Foundation, Woodbridge: Boydell 
Philp, B 2003. The Discovery and Excavation of Anglo-Saxon Dover, Kent Monogr Ser 9, Dover: Kent Archaeological Rescue Unit

Pickles, T 20II. 'Anglo-Saxon monasteries as sacred places: topography, exegesis and vocation', in Sacred Text - Sacred Space (eds P Thomas and J Sterrett), 35-55, Leiden: Brill

Rahtz, P 1973. 'Monasteries as settlements', Scott Archaeol Forum, 5, I25-35

Reynolds, A 2003. 'Boundaries and settlements in later sixth- to eleventh-century England', in Boundaries in Early Medieval Britain (eds D Griffiths, A Reynolds and S Semple), 98-139, Anglo-Saxon Studies in Archaeology and History I2, Oxford University School of Archaeology

Reynolds, R 20I0. 'Fish remains', in Thomas 2010a, I57-63

Reynolds, R 20II. 'Anglo-Saxon fish remains Lyminge, Kent', unpublished report, 〈http:// www.reading.ac.uk/web/FILES/archaeology/ LymingeReynolds2oII.pdf > (4 Dec 20I2)

Reynolds, R 2013. 'Lyminge 2010: analysis of fish remains from environmental samples', unpublished report, 〈http://www.reading. ac.uk/web/FILES/archaeology/Reynolds 20I3_-_fish_from_20IO_environmental_ samples.pdf $>$ (9 Apr 2013)

Richardson, A F 2005. The Anglo-Saxon Cemeteries of Kent, 2 vols, BAR Brit Ser 39I, Oxford: Archaeopress

Rigold, S E 1968. "The "double minsters" of Kent and their analogies', f Brit Archaeol Ass, 3rd ser, 3I, 27-37

Rollason, D W 1982. The Mildreth Legend, Leicester University Press

Scull, C I991. 'Post-Roman phase I at Yeavering: a re-consideration', Medieval Archaeol, $35,5 \mathrm{I}-63$

Scull, C 20II. 'Assessment of material culture assemblages (copper-alloy, bone/antler and vessel glass) from SFBs I, 2 and 3', unpublished report, 〈http://www.reading. ac.uk/web/FILES/archaeology/Scull_20II_-20IO_small_finds.pdf $>$ (4 Dec 2012)

Semple, S (ed) 2007. Early Medieval Mortuary Practices, Anglo-Saxon Stud Archaeol Hist I4, Oxford University School of Archaeology

Serjeantson, D and Woolgar, C M 2006. 'Fish consumption in medieval England, in Food in Medieval England: diet and nutrition (eds C M Woolgar, D Serjeantson and T Waldron), I02-30, Oxford University Press

Sykes, N J 2007. The Norman Conquest: a zooarchaeological perspective, BAR Int Ser I656, Oxford: Archaeopress
Tatton-Brown, T i988. 'The churches of Canterbury diocese in the eleventh century', in Minsters and Parish Churches: the local church in transition 950-I200 (ed J Blair), IO5-I8, Oxford Comm Archaeol Monogr I8, Oxford

Thomas, G 2010a. The Later Anglo-Saxon Settlement at Bishopstone: a downland manor in the making, CBA Res Rep I63, York: Council for British Archaeology

Thomas, G 20Iob. 'Bringing a lost Anglo-Saxon monastery to life', Medieval Archaeol, 54, 409-I4

Thomas, G 20II. 'The big dig: Bishopstone and Lyminge', British Archaeology, II9, 42-8

Thomas, G 2012. 'The prehistory of medieval farms and villages', in Medieval Rural Settlement: Britain and Ireland AD 800-I600 (eds N Christie and P Stamper), 43-62, Macclesfield: Windgather

Thomas, G and Knox, A 2012. 'A window on Christianisation: transformation at Anglo-Saxon Lyminge, Kent, England', Antiquity, 86 (334), Project Gallery, 〈http://www. antiquity.ac.uk/projgall/thomas334/ $\rangle$ (28 Mar 2013)

Tipper, J 2004. The Grubenhaus in Anglo-Saxon England, Yedingham: Landscape Research Centre

Ulmschneider, K 20II. 'Settlement hierarchy', in Hamerow et al 20II, I56-7I

Wallenberg, J K 1934. The Place-names of Kent, Uppsala: Appelbergs Boktryckeriaktiebolag

Welch, M 2007. 'Anglo-Saxon Kent to AD 800', in The Archaeology of Kent to $A D 800$ (ed J H Williams), I87-250, Woodbridge: Boydell

Williams, $\mathrm{H}$ 2002. 'Cemeteries as central places: landscape and identity in early AngloSaxon England', in Central Places in the Migration and Merovingian Periods (eds B Hardh and L Larsson), 34I-62, Papers from the 52nd Sachsensymposium, Lund: Almqvist

Williams, $\mathrm{H}$ 2006. Death and Memory in Early Medieval Britain, Cambridge University Press

Witney, K P 1976. Futish Forest: a study of the Weald of Kent from $450 A D$ to $1380 A D$, London: Athlone

Yorke, B 1999. 'The reception of Christianity at the Anglo-Saxon royal courts', in Gameson I999, I52-73

Yorke, B 2003. Nunneries and the Anglo-Saxon Royal Houses, London: Continuum

Yorke, $\mathrm{B}$ 2006. The Conversion of Britain 600-800, Harlow: Pearson Longman 


\section{RÉSUMÉ}

L'archéologie monastique anglo-saxonne a été entravée par l'ampleur limitée des recherches passées et par l'importance prépondérante qu'elles ont accordée aux bâtiments principaux. Dans cet article, l'auteur s'appuie sur les résultats d'une campagne de recherche archéologique en cours qui tente de rétablir l'équilibre au moyen d'un programme ambitieux de fouilles en aire ouverte mené à Lyminge, dans le Kent, site d'un double monastère royal fondé au VIIe siècle. Les résultats de cinq saisons complètes de travail sur le terrain sont évalués et contextualisés sous la forme d'une séquence narrative qui souligne le dynamisme de Lyminge en tant que colonie monastique anglo-saxonne. Ce faisant, l'étude montre clairement comment les premiers monastères médiévaux étaient implantés dans le paysage en faisant spécifiquement référence au Kent anglo-saxon, un contexte régional qui offre des aperçus importants sur la manière dont le processus de fondation des monastères a redéfini des lieux centraux antérieurs à l'importance politico-religieuse et à l'action sociale anciennes.

\section{ZUSAMMENFASSUNG}

Die angelsächsische monastische Archäologie war durch das geringe Ausma $\beta$ früherer Untersuchungen und deren bevorzugtem Schwerpunkt auf bedeutende Gebäude eingeschränkt. Diese Abhandlung stützt sich auf die Ergebnisse einer laufenden Kampagne archäologischer Forschungen, die nunmehr über ein ambitioniertes Programm freiflächiger Ausgrabungen in Lyminge, Kent, einem im siebten Jahrhundert gegründeten Doppelkloster, das Gleichgewicht wiederherstellen. Die Ergebnisse fünf abgeschlossener Feldforschungssaisonen werden bewertet und in narrativer Abfolge kontextualisiert, mit besonderem Augenmerk auf den dynamischen Charakter von Lyminge als eine angelsächsische monastische Siedlung. Dabei richtet die Studie die Aufmerksamkeit ganz besonders darauf, wie die frühmittelalterlichen Klöster, mit spezifischem Bezug auf das angelsächsische Kent, in die Landschaft gesetzt wurden, wobei der regionale Kontext wichtige Einblicke dazu vermittelt, wie durch den Prozess monastischer Gründungen einstmals zentrale Stätten langjähriger politisch-religiöser Bedeutung und sozialen Aktivitäten neu definiertwurden. 